Portland State University

PDXScholar

1973

\title{
An Analysis of the Effects of Background Variables on Attitudes and Policy at the Bonneville Power Administration
}

Philip George Millam

Portland State University

Follow this and additional works at: https://pdxscholar.library.pdx.edu/open_access_etds

Part of the Political Science Commons

Let us know how access to this document benefits you.

Recommended Citation

Millam, Philip George, "An Analysis of the Effects of Background Variables on Attitudes and Policy at the Bonneville Power Administration" (1973). Dissertations and Theses. Paper 1997.

https://doi.org/10.15760/etd.1996

This Thesis is brought to you for free and open access. It has been accepted for inclusion in Dissertations and Theses by an authorized administrator of PDXScholar. Please contact us if we can make this document more accessible: pdxscholar@pdx.edu. 
AN ABSTRACT OF THE THESIS OF Philip George Millam for the Master of Arts in Political Science presented February 27, 1973.

Title: An Analysis of the Effects of Background Variables on Attitudes and Policy at the Bonneville Power Administration.

APPROVED BY MEMBERS OF THE THESIS COMMITTEE :
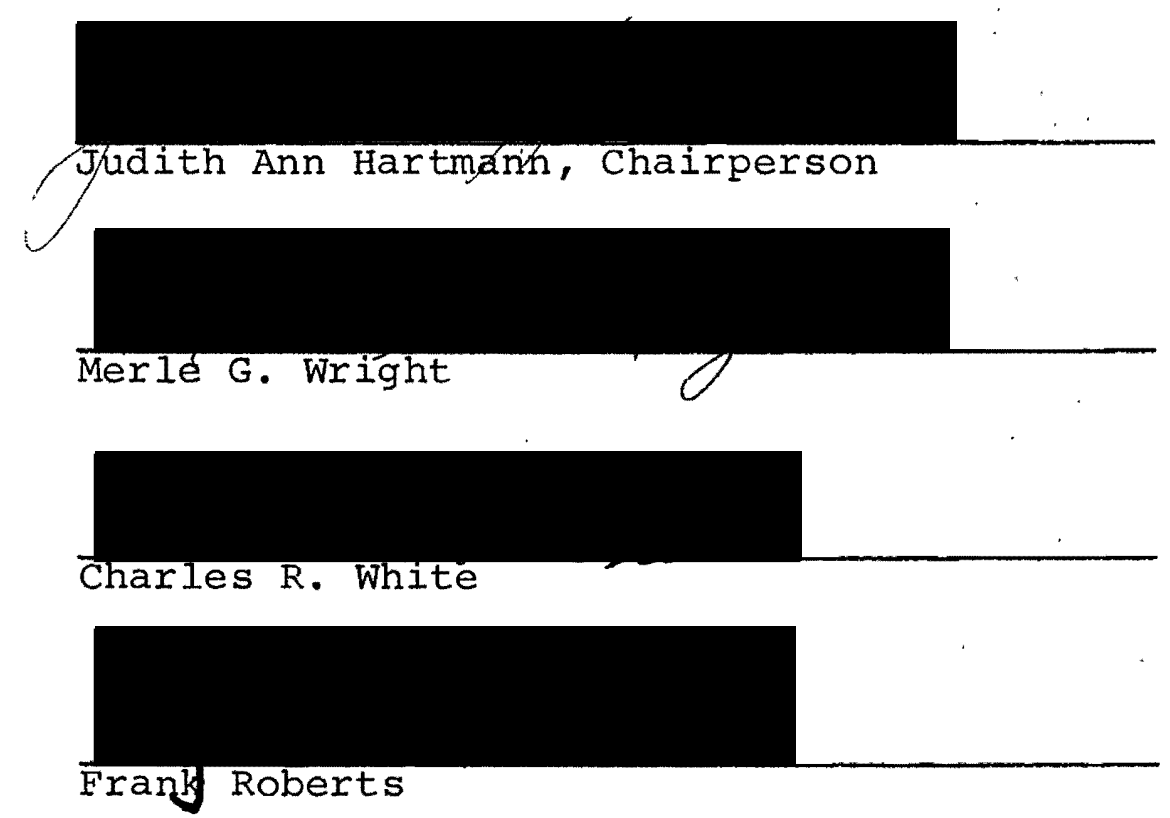

The question is asked whether or not background, education, and training of middle and upper level bureaucratic personnel affects policy outcomes. The Bonneville Power Administration ( $B P A$ ) serves as the agency examined. A written questionnaire sent to a random sample of BPA executives sought data on background variables with the intent of 
making comparisons. Most BPA executives are found to share very similar education and training backgrounds--namely, engineering studies at Northwest state universities. Also, attitudes measured are found to be more similar than different on most issues for the agency as a whole. This phenomenon is explained in terms of a self-selection process whereby individuals of similar persuasions, skills, and values seek out educational and career opportunities with which they are comfortable and which attract others of similar perspectives. The individual is seen to narrow his viewpoint while reinforcing his existing values. At BPA, the dominant perspective is that of the engineer. The effect of this engineering perspective is seen in policy outcomes in energy matters relating to growth, efficiency, environment, and economy. 
AN ANALYSIS OF THE EFFECTS OF BACKGROUND VARIABLES ON ATTITUDES AND POLICY AT THE BONNEVILLE POWER ADMINISTRATION

by

PHILIP GEORGE MILIAM

A thesis submitted in partial fulfillment of the requirements for the degree of

\author{
MASTER OF ARTS \\ in \\ POLITICAL SCIENCE
}

portland State University
1973 
TO THE OFFICE OF GRADUATE STUDIES AND RESEARCH:

The members of the committee approve the thesis of Philip George Millam presented February 27, 1973.
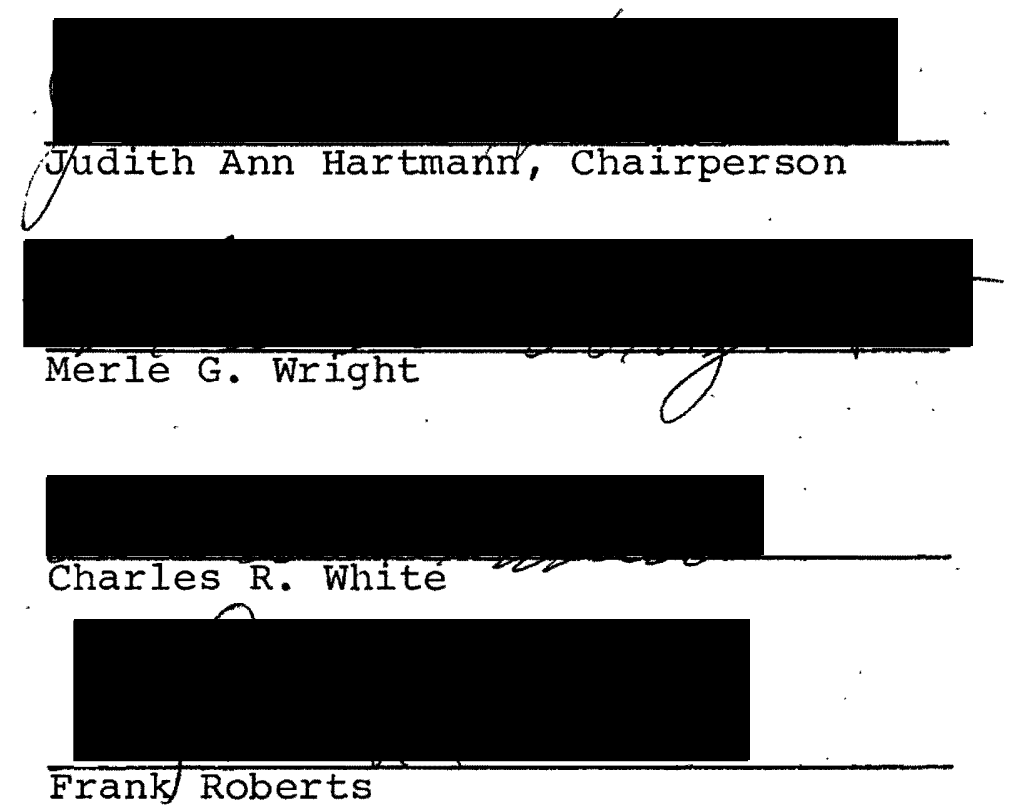

APPROVED :

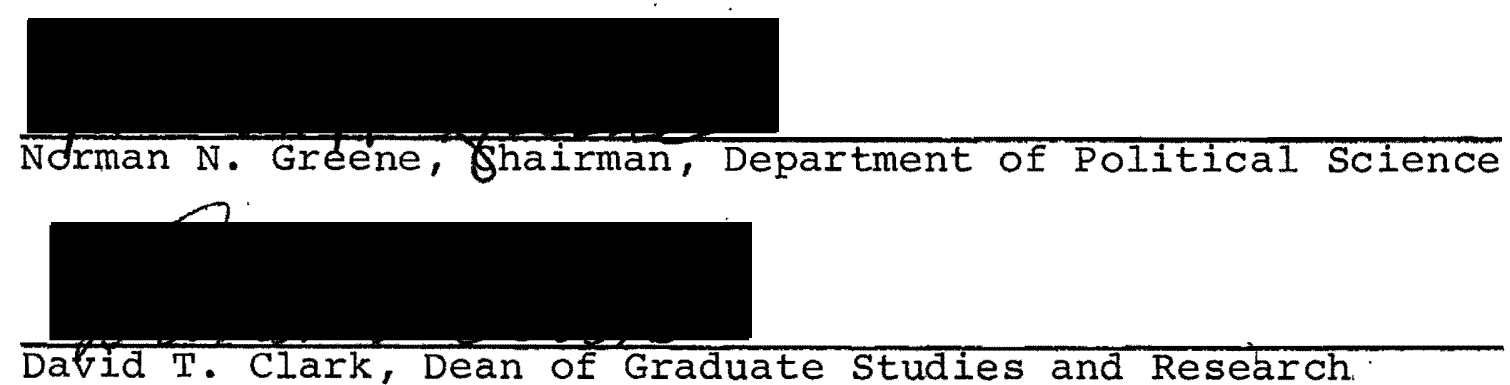


TABLE OF CONTENTS

PAGE

LIST OF

TABLES

. . . . . . . . . . . . .

$\mathrm{V}$

CHAPTER

I INTRODUCTION . . . . . . . . . . . . 1

II REVIEW OF THE LITERATURE . . . . . . . . 5

III BONNEVILLE POWER ADMINISTRATION. . . . . . 9

IV A PERSONNEL PROFILE. . . . . . . . . . 22

$\mathrm{V}$ ATTITUDES AND PERCEPTIONS. . . . . . . . 32

Introduction. . . . . . . . . . 32

Open-Ended Attitudinal Data . . . . 32

Environmental Attitudes . . . . . 39

Statement A: Environmentalists'

Concerns. . . . . . . . . . 41

Statement B: Aluminum Plants. . . 43

Statement C: Necessity of Growth. 45

Statement D: Reduce Economic

Expansion . . . . . . . . . 47

Statement E: Conservation of
Energy. . . . . . . . . 49

Environmental Section Summary. . . 51

Functional Role... . . . . . 51

Statement F: Power Shortages. . . 52

Statement G: Policy Disagreement. $\quad 54$

Statement H: Power Contracts. . . 56

Statement I: Compatibility of 58

Statement J: Public Interest. : 60

Statement K: Responsiveness ... 61 
Attitudinal Summary . . . . . . . 63

VI DISCUSSION •. . . . . . . . . 66

VII SUMMARY AND CONCLUSIONS. . . . . . . . . . 78

General Summary . . . . . . . . 78

Conclusions . . . . . . . . . . 82

BIBLIOGRAPHY • . . . . . . . . . . . . . . . 85

APPENDIX A METHODOLOGY • . . • • . . . . . . . 87

APPENDIX B SURVEY QUESTIONNAIRE. • • • • • . . • . . 90 
LIST OF TABLES

TABLE

PAGE

I Average Age by Grade . . . . . . . . . . 22

II Education Index by Grade . . . . . . . . . . 23

II Major Subjects studied . . . . . . . . . . 24

IV Location of College or University Attended . • . 25

$\mathrm{V}$ Northwest State Schools Attended . . . . . . 25

VI Pre-BPA Employment . • • • • . • • • • • . 26

VII First Preference: Post-BPA Employment . . . . 27

VIII Year of Initial Employment . . . . . . . . . 29

IX Per Cent of Sample Claiming Five or Ten

Point Veterans' Preference. . . . . . 30

$\mathrm{X}$ Perceptions of Beneficiaries of BPA Policy . : . 33

XI Policy Influence . . . . . . . . . . . . 35

XII Perceptions of Self-Influence: Total Sample . . 36

XIII Self-Influence Index by GS Level . . . • • . 36

XIV Self-Influence Index by Age. . . . . . . . . 37

XV Environmentalists' Concerns. . . . . . . . . 42

XVI Aluminum Plants. . . . . . . . . . . . 44

XVII Necessity of Growth. . . . . . . . . . . 46

XVIII Reduce Economic Expansion. . . . . . . . . 48

XIX Conservation of Energy . . . . . . . . . . 50

$\mathrm{XX}$ Power Shortages. . . . . . . . . . 53

XXI Statement G Percentage Spread. . . . . . . . 54

XXII Policy Disagreement. • . • . . . . . . . 55

XXII Statement H Percentage Spread. . . . . . . . 57 
XXIV Power Contracts . . . . . . . . . . . 57

XXV Compatibility of Functions. . . . . . . . . 59

XXVI Public Interest . . . . . . . . . . . 61

XXVIT Responsiveness. . . . . . . . . . . . 62

XXVIII Difference between Largest and Smallest Mean

(Delta) for Each Variable and Statement. . 64

XXIX A Comparison of Means for All statements. • . 70

xxX Sample and Returns. . . . . . . . . . 89 
CHAPTER I

\section{INTRODUCTION}

The purpose of this study is to attempt to determine if the background, training, and education of middle and upper level bureaucratic personnel have a significant effect on policy. formulation and execution. Research on the background of bureaucrats is sparse and more is long overdue, but its importance has not been overlooked:

[The] - . great impact of government and public. affairs upon almost all aspects of American life suggests, in turn, the importance of furthur attention to the crucial role of all government executives, particularly those in the federal government. However, this role cannot be fully understood, much less carefully considered in terms of the future, without more knowledge concerning the social origin, education, mobility, attitude, and personality of those who occupy positions of trust and responsibility. 1

Warner suggests that it is reason enough to study federal executives because of their important roles in bureaucratic. decision making. He goes on to say that "The idea that the social composition and the outlook of a civil or military bureaucracy have an important bearing upon its actions is by no means new. . . ." 2 This statement implies that studying personnel is important not only because their decisions and

${ }^{1}$ W. Lloyd Warner, et al. , The American Federal Executive, (New Haven: Yale U. Press, 1963), p. 2 .

$$
2 \text { Ibid. , p. } 5 \text {. }
$$


actions have broader consequences, but also because a different "social composition" or "outlook" might result in different actions.

This study seeks to add information that may help to confirm or deny such implications by looking at a particular federal bureaucracy, the Bonneville Power Administration (BPA) with an eye to the following questions: (1) How do BPA personnel differ and how are they similar? (2) Are different or similar backgrounds, training, and education associated with different or similar attitudes, perceptions, and values? (3) Is BPA policy affected by any such differences or similarities? These questions directed at BPA operate within broader questions of representation and values. Since no one in a bureaucracy is elected, whose values tend to be represented and whose neglected? How are values injected into the bureaucratic and governmental process? What safeguards exist that can protect democracy from abuses of bureaucratic governing?

Despite the importance of these questions, there has been little research directed specifically at them. Dye notes that ". . we do not have very many studies which systematically examine the linkage between specific institutions, processes, and behaviors and the content of public policy.". 3

3 Thomas R. Dye, Understanding Public Policy, (Englewood Cliffs, N. J.: Prentice-Hall, 1972), p. 266. 
[Emphasis Dye's]. While systematic research is somewhat lacking, numerous scholars have argued persuasively--albeit from circumstantial evidence--that the backgrounds of certain bureaucratic personnel may indeed be reflected in policy matters.

Preliminary to a discussion of these works, however, certain assumptions must be stated. First, policy is not made or executed in a vacuum. Policy is formulated and carried out by people, and people are susceptible, to certain pressures, biases, goals, attitudes, and values. Blau confirmed this in his classic Dynamics of Bureaucracy when he found that "Officials redefined procedures in terms of the dominant objectives of their tasks, and these changes, in turn, gave rise to further amplifications of procedures in the interest of other objectives." 4 second, people at virtually all levels in a bureaucratic hierarchy have an opportunity to make policy. Kaufman stresses this in the Forest Ranger:

By emphasizing one function over others, by aggressiveness or passivity, by inventiveness or adherence to the status quo, by risking the displeasure of superiors or colleagues or neighbors or by following the path of least resistance, by enthusiastic or indifferent or reluctant performance, the Rangers in effect modify and even make policy--sometimes without

${ }^{4}$ Peter M. Blau, The Dynamics of Bureaucracy: A Study of Interpersonal Relations in Two Government Agencies, Revised Edition, (Chicago: Univ. of Chicago, 1963), p. 35. 
knowing it. 5

Because people at all levels make and carry out policy, the effect, if any, of background, education, and training should be of interest to students of government, politics, and administration.

${ }^{5}$ Herbert Kaufman, The Forest Ranger: A Study in Administrative Behavior, (Baltimore: Johns Hopkins, 1967), p. 65 . 
CHAPTER II

\section{REVIEW OF THE LITERATURE}

Among the existing studies which draw or imply a connection between background of personnel and policy is Wilkinson's study in Gentlemanly. Power. Wilkinson argues that the perspective of the British governing elite was affected by the strict and harsh education offered by the exclusive public schools. The public school tradition, he suggests, with its emphasis on teamwork, fair play, conformity, discipline, and memorization have helped to cement the direction of some. British policies. ${ }^{6}$ wilkinson points to lack of military foresight which led to unnecessary loss of life during World War I and to post war "appeasement" as being partly a result of ". . . attitudes engendered by public school education [which] reinforced rather than offset a shortsightedness that British leadership may have possessed anyway." 7 Wilkinson goes further and links the British constitutional system with the public school tradition of relying on "character" instead of checks and balances in its approach: "Like public school authority, British

${ }^{6}$ Rupert Wilkinson, Gentlemanly Power: British Leadership and the Public School Tradition, (London: Oxford Univ. Press, 1964).

${ }^{7}$ Ibid., p. 87 . 
Cabinet government has depended for responsibility on human character rather than on written laws." 8 while no similar educational system exists in the United States, Wilkinson provides some footholds with which to continue further investigation.

Morris Janowitz' study, The Professional Soldier, focuses on the American military hierarchy and offers further insights into the effect of background, education, and training on bureaucratic behavior. Noting that a high percentage of American generals and admirals attended one of the military academies, Janowitz states that academy education is:

- . the source of the pervasive 'Iike-mindedness' about military honor and for the sense of fraternity which prevails among military men. The professional military perspective until 1950 must be understood as an amalgam of the conservative background of its cadets and the technical and engineering curriculum of West Point and Annapolis.9

Seldom has a scholar so clearly stated the link between perspective and background. The policy consequences of such like-mindedness ċan only be speculated upon, but perspective may well be an important factor in the approach bureaucratic personnel take toward policy.

Another major work that considers background is

${ }^{8}$ Ibid., p. 33 .

9 Morris Janowitz, The Professional Soldier: A Social and Political portrait, (New York: Free Press, 1971), p. 127 . 
Herbert Kaufman's The Forest Ranger. Kaufman observed that future forest rangers were willing to conform to the expected rigors and regulations even before official selection:

- . they had many of the qualities and attitudes the service wants in its men, and they were ready even prior to their professional schooling for the demands that would be made upon them later on. 10

This self-selection process reinforces similarity of attitudes, but uniformity is likely to be even further amplified by formal schooling. Kaufman notes that there are only a limited number of schools offering degrees in forestry, and that:

the existence of a widespread consensus on technical matters within the agency is . . not surprising. In other words, many decisions and actions taken in the field are implanted in these men during their pre-service education.'. . .11

Again, the link is suggested between background, attitudes, and technical uniformity, but the actual influence of these forces on policy is only educated guesswork:

Uniformity of attitudes and technical consensus was recognized in yet another study, this time in the Justice Department. Navasky's Kennedy Justice observed that Robert Kennedy's legion of Ivy League lawyers had remarkably similar ideas on the role of negotiation versus confrontation on issues involving challenges to their concept of federalism.

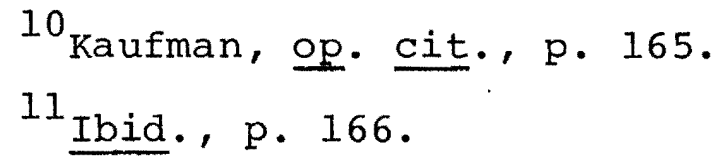


As it affected school desegregation suits, Navasky argues that the similar backgrounds and education of the young Ivy League attorneys may have had an impact on policy because the use of possibly violent action was uniformly repugnant to them. Thus, by emphasizing negotiation over possible violence, school desegregation was delayed by the personnel within the Justice Department. ${ }^{12}$

The above studies universally link certain aspects of background, training, and education with attitudes and outlooks that likely had an effect on policy. Unfortunately, little comparative research has been done in this area, thus leaving it to educated speculation to determine the relative impact these background variables may have on attitudes and policy. Because of the myriad variables that influence people, this state of affairs is likely to continue. However, if differences or similarities in attitudes and perspectives can be determined to be related to certain background variables, then the degree of speculation may be somewhat lessened. In order to set the stage for such analysis, it is necessary to present a brief historical perspective of the agency to be studied--the Bonneville Power Administration.

12 Victor s. Navasky, Kennedy Justice, (New York: Atheneum, 1971), pp. 184-221. 
CHAPTER III

BONNEVILLE POWER ADMINISTRATION ${ }^{13}$

Bonneville Power Administration (BPA) takes its name from Bonneville Dam which was constructed on the Columbia River during the 1930s. It was the construction of this dam and the resulting controversy that provided the motivation to create BPA. Bonneville was primarily intended to be a navigational dam and lock to permit river navigation further up the river. To diversify the dam, the corps of Engineers (Corps) installed hydroelectric generators. But the expected generating potential of the dam far exceeded the demand for electricity in the area at that time. The obvious problem was what to do with the excess generating potential.

Three proposals were offered to solve the problem. Some business and private power interests felt that the Corps would be sympathetic to their goals, and these groups wanted the corps to market the power that was generated.

${ }^{13}$ The author has drawn heavily from two sources in this chapter. They are: Charles McKinley, Uncle Sam in the Pacific Northwest: Federal Management of Natural Resources in the Columbia River Valley, (Berkeley: U. of. California, 1952), pp. 157-228, and Daniel M. Ogden, "The Development of Federal Power Policy in the Pacific Northwest," (Photostated PhD. dissertation, University of Chicago, 1949), Vol. 1. 
The strong public power groups preferred a separate agency to market the power, thus reflecting their fears that the Corps would not adequately favor their interests. Another group, led by Senator Pope of Idaho, favored a Columbia Valley Authority similar to the Tennessee Valley Authority. However, progress in construction of Grand Coulee Dam by the Bureau of Reclamation (BOR) proved to be the factor that forced the final decision. The BOR wanted to market the power to be generated at its dam while the corps wanted to sell the power from Bonneville. The Pacific. Northwest Regional Planning Council foresaw the potential confusion and coordination problems if two separate agencies marketed power in one region. The Council recommended that a separate marketing agency be created and that interties be built between Bonneville and Grand Coulee to better serve power needs. President Franklin Roosevelt "compromised" and pushed for a "temporary" agency under the, Department of the Interior to construct the interties and market the power. The Bonneville Project Act of 1937 successfully passed on a wave of New Deal infatuation with public power. BPA was born.

The Bonneville Project Act charged the new agency with: (1) encouraging electrical usage, (2) giving priority and preference to rural and domestic power consumers, and public power groups, and (3) operating in the public 
good. 14, Other specific sections of the law state that no power contract may be for a period longer than twenty years and that the administrator:

- . may cancel such contract upon five years' notice in writing if in the judgment of the administrator any part of the electric energy purchased under said contract is likely to be needed to satisfy the requirements of the said public bodies or cooperatives. 15

The statute also gives the administrator authority over the resale rates charged the public by a BPA customer. ${ }^{16}$ (However, this authority has never officially been used.) The statute also makes it clear that the Corps and the BOR will build and operate the dams, but only BPA will market or transmit power. BPA is forbidden to interfere in running the projects.

BPA began constructing high voltage transmission lines in 1938 when Congressional appropriations finally passed. Acting on various directives, BPA began building a power grid that linked Bonneville Dam and Grand Coulee with Seattle and Tacoma. Other lines would radiate out from these points to smaller cities and towns. The policies of BPA (as required by the Bonneville Act) favored public power groups, and the already strong public power sentiments stimulated

14 Bonneville Project Act, 16 U.S.C. 832 Chapter 12B (as amended, revised, and supplemented).

${ }^{15}$ Ibid., section $5(a)$. ${ }^{16}$ Ibid. 
many condemnation proceedings against private power companies. But the initial direction of BPA was to be permanently changed by two events. One was world war II and the other was the assumption of the job of administrator by Paul Raver on the death of J. D. Ross in 1939.

The war placed increased demands on the energy resources of the Northwest. Up to this time, BPA had interties only with public power concerns. The war production demands required "temporary" interties with many private companies. This public-private power grid, coordinated by BPA, became known as the Northwest Power Pool. Before the war, power sales to private power companies were on a one year renewable basis. Pressures of war needs prompted a change in policy so that the private companies could buy power on a firm basis for the duration of the war. Despite the statutory provisions for resale rate restrictions, no price limitations were included in the contracts. Rapid industrial expansion during the war was significant to BPA because, upon the termination of hostilities, the policy of sales to private companies continued. Private power had become so dependent on BPA for energy that a cutback to prewar policies might have caused shortages to the public served by private power. BPA feared that it would be blamed for the shortages, and, in 1953, entered into the first twenty-year contracts with privately owned power companies. War requirements and regional economic planning were 
largely responsible for the establishment and expansion of the aluminum industry in the 1940s. But Administrator Paul Raver's zeal in preparing for the light metals industry had much to do with the scope and permanence of the plants. Before the war, Raver ordered studies to be conducted for likely sites for aluminum mills. Included in these studies were detailed forecasts of regional wage levels, labor "stability," and degree of unionization which would be of interest to potential industrialists. After Pearl Harbor the light metals industry blossomed all over the Northwest, but especially along the Columbia River. The aluminum industry requires huge amounts of electricity because it reduces alumina (produced from bauxite) to aluminum through a process of electrolysis. Post-war aluminum demand did not diminish as much as had been predicted and the reduction mills continued their production and demand for energy. BPA's role in this industry is to sell so-called surplus power at greatly reduced rates.

BPA's function expanded during the 1950s to include responsibility for transmitting most of the electric energy from most sources within the Columbia River watershed. Specifically, BPA operates in Oregon, Washington, Idaho, Western Montana, and small portions of Utah, Wyoming, and Nevada. BPA's mission has grown from marketing power from two federal dams to where it now markets and transmits power from many federal and public projects and "rents" its 
transmission facilities to both public and private power groups. BPA transmits over 16 million kilowatts of energy from federal dams alone, and has built and maintains almost 12,000 miles of transmission lines and right-of-way clearings. The increased sophistication of the agency is seen in a treaty with Canada that permits storage dams in the Rocky Mountains to accumulate water for winter low-water periods. A complex direct current intertie with southern California makes it possible for BPA and the Southwest to trade power during seasonal shortages. The degree of regional interdependence (and likely a picture of the future) was shown in 1970 when an equipment malfunction near The Dalles, Oregon, contributed to an eight minute power outage in Juarez, Mexico.

BPA has not been a static agency; its goals and purpose have changed as it matured. BPA began as a relatively unsophisticated energy marketing agency. That original role has since expanded to include the function of coordination and planning for most Northwest electric energy matters. This expanded role came about largely as a response to a felt need. BPA was the logical agency to attempt to manage the technical and political disputes that arose among the various public and private utilities. Through BPA's efforts, the region as a whole has been better coordinated in energy matters than if there were no central body to settle conflicts and plan for future needs. 
Yet it is the use of $\mathrm{BPA}$ 's increasing influence that raises many political questions. The direction that BPA seems to be taking--that all demand for electric energy must be met--involves direct and indirect conflicts on at least three issues: economy, energy, and the environment. Because BPA enjoys a central position as coordinator of all important Northwest power policy, and because power groups must look to BPA for leadership, BPA's influence has become far reaching. This influence is reinforced by the fact that BPA directly provides 50\% of the region's power needs and transmits $80 \%$ of all the electrical energy. Northwest industry directly or indirectly receives two-thirds of its power from BPA. ${ }^{17}$ These facts lend credibility to the notion that BPA does indeed provide the majority of control and influence on Northwest power policy.

What, then, can be said about this power policy as it relates to BPA? First, it is service oriented. That is, BPA strives diligently to serve public and private utilities and industry with efficient assistance. Because the public is only indirectly served through BPA's customers, the utilities and industry are seen as the immediate clientele. There is some feeling (detected in personal interviews) that BPA is itself a utility whose main function is to serve

${ }^{17}$ U.S., Department of the Interior, Bonneville power Administration, About BPA, Information Office, July 1972, p. 5 . 
other utilities. Concurrent with this notion is the concept that BPA therefore has a public utility responsibility to serve all those who demand power, whether public or private groups, without discrimination. Yet, the Bonneville Act says that BPA will discriminate if necessary. Second, BPA tends to be demand oriented. The entire thrust of BPA economic and industrial studies is to encourage, plan for, and meet future power needs. In the past BPA encouraged growth for two reasons--existence of power and perceptions of benefiting the economy. Today, both these reasons are suspect because power is no longer available in unlimited supply and meeting unlimited demand seems to promote unlimited growth. Growth and environmental goals may be at odds with each other.

Other BPA policy may be seen as corollaries of the service and demand orientations. Because BPA feels that limitations on energy mean inevitable limitations on the economy and standard of living, the agency is constantly pushing for new generating facilities to better serve its clientele. The latest manifestation of this trend is seen in the Hydro-Thermal Program. This program is the product of the Joint Power Planning Council (JPPC) which is made up of 109 private and public power groups in the Northwest. (BPA organized the JPPC and an assistant administrator from BPA chairs the Council.) The program calls for the Federal government to expand existing hydro-electric dams (and the 
Hanford reactor) to their full generating capacity and for public and private utilities to jointly finance nuclear power plants. ${ }^{18}$ The Trojan Project (nuclear) and the Centralia steam project (coal fired) are part of this program. BPA believes that this program will alleviate somewhat the power "deficit" forecast for the middle and late 1970s. The Hydro-Thermal Program is in fact a creation of BPA and exemplifies its concern for expediting new sources of power in addition to its role as planner, coordinator, and seller of energy •

However, BPA's non-statutory concern for meeting all demand for power is inextricably related to its concern for Northwest economic growth. The Hydro-Thermal Program seeks not only to increase generating capacity to meet present demands, but also to provide for future economic expansion and future demands. This fact is openly stated in a BPA publication:

The economy of the region would be bolstered both by maintaining low power rates and by expansion of the electro-process [aluminum and other light metals] industries and the concomitant growth in residential, commercial and industrial loads of the areas utilities. 19

Approximately $40 \%$ of BPA's energy sales are directly to heavy industry at very low rates. The revenues from these

${ }^{18}$ See U.S., Department of the Interior, Bonneville Power Administration, A Ten Year Hydro-Thermal Power Program for the Pacific Northwest, 1969.

$$
{ }^{19} \text { Ibid., p. } 28 .
$$


industrial users have provided a dependable income for BPA and have permitted sales of energy that otherwise would have gone to waste or not been generated even though the capacity existed. As residential and commercial demand increases (largely due to electric home heating and heavy appliances), BPA is faced with a dilemma. By statute BPA must give priority to public utilities and residential users, thus possibly forcing BPA to curtail sales to the electro-process industry. But to avoid the prospect of abandoning its most reliable customer, $\mathrm{BPA}$ has designed the Hydro-Thermal Program to insure the present and future growth of the aluminum industry while satisfying the residential user.

Policy at BPA is action or inaction (or proposals of either) directed toward some goal. Policy need not be written down as a formal statement; policy can be a subtle emphasis that may only be perceived by someone within the agency, or a close observer. Thus, an observer must look not only at what an agency says it does, but what it actually does. For example, the former BPA administrator, Russ Richmond, claims to have eliminated the program to encourage new industrial customers. Yet the Hydro-Thermal Program is aimed partly at expansion of present industry.

Some policy at BPA is a response to a higher authority. BPA is formally a sub-agency within the Department of the Interior responsible to the assistant secretary of the Interior for water and Power Resources; however, BPA is 
dependent upon Congress for all appropriations for construction, maintenance, and operations. No funds from the sale of energy are retained by BPA to use as it pleases. Instead, BPA amortizes the cost of the federal hydro-electric projects from the sale of power. Any surplus income reverts to the Treasury.

Despite BPA's dependence on Congress for appropriations to survive, several factors work toward independence. One is that BPA is the only large federal bureaucracy with headquarters outside of the Washington, D.C. area. Another factor is that the highly sophisticated and complex functions of BPA are gladly left to the local "experts" who presumably know what is best out in oregon. Also, the Department of the Interior field representative with responsibility to oversee all Interior functions in the Portland, Oregon area is a political appointee and a former. BPA. employee. Finally, the Federal Power Commission wields little direct influence over BPA except to consider power rates and long-range energy plans. These factors are evidence that $B P A$ is able to maintain a relatively high degree of independence. Although BPA is financially dependent on Congress, it is functionally rather independent from hierarchical policy dictates.

Despite the brevity of this 100 at BPA, several policy trends are readily observable or assumable: (1) BPA is dedicated to serving its perception of the needs of its 
clientele and the Northwest as a whole in energy matters; (2) in addition to its statutory responsibilities BPA has assumed the role of planner, coordinator, provider, and peacemaker for Northwest power policy; and (3) BPA feels a responsibility to meet all present and future energy demand in an expanding economy. These broad observations on policy. are perhaps a shelter within which hundreds of directives, procedures, and other policy statements operate.

An historical glimpse of BPA was necessary before launching into a personnel study because the only explanation for some agency behavior is past practice and tradition. The historical development of an institution tends to program the pattern for its later direction which new generations of personnel may fail to understand or challenge. Historical development also does much to determine the function of an agency which in turn gives clues to the conflicts and pressures faced by agency personnel.

Human history can be approached in at least two ways. One is to simply examine past events and report on them. Another is to attempt to analyze why people have chosen one particular course of action over another given a generally agreed upon set of "facts." An analysis of the latter type stresses not only facts, but people and their perspectives and the influences on those perspectives. Why, for example, do intelligent people examining identical information come to quite different conclusions? It is the hypothesis of 
this study that an individual's background does much to shape his or her perspective, and that this perspective is a key factor in influencing agency policy. With this emphasis in mind, the study can now turn to an examination of the background of certain BPA personnel in the hope that a better understanding of agency people will lead to better explanations of present policy and perhaps even better prediction of future policy. 
CHAPTER IV

\section{A PERSONNEL PROFILE}

The role of the BPA executive cannot be accurately established until something is known about differences and similarities of background, training, and education. It is doubtful that there is any employee that would fit the term "average"; however, patterns and trends do exist which will offer insights into attitudes and behavior.

Based on returned questionnaires, $2097 \%$ of the BPA executives are male. As Table I indicates, age tends to rise with GS level.

TABLE I

AVERAGE AGE BY GRADE

\begin{tabular}{lccccccc}
\hline & Total & GS 11 & GS 12 & GS 13 & GS 14 & GS 15 \\
\hline \multirow{2}{*}{ Age in years } & 44.7 & 39.0 & 43.0 & 48.0 & 54.0 & 56.0 \\
& $N=109$ & $N=33$ & $N=37$ & $N=28$ & $N=9$ & $N=7$ \\
\hline
\end{tabular}

A BPA executive is slightly more apt to consider himself a line worker as opposed to a staff worker. sixty-eight per cent (based on location of the greater portion of high

${ }^{20}$ See Appendix A for methodology and Appendix B for the questionnaire. 
school attended) are Northwest natives--Washington, Oregon, Idaho, and Western Montana. Sixty-one per cent of the Northwest natives are from metropolitan areas--Seattle, Tacoma, Spokane, Portland, and Eugene--while $39 \%$ are from non-metropolitan or rural areas within the Northwest.

The average level of education attained is only slightly below that of a college graduate. Ninety-three per cent have attended "some college" or higher. Seventy-nine per cent have one or more degrees while $14 \%$ have gone no further than "some college." Seven per cent have only a high school education or less. Twenty-five per cent have done work beyond the baccalaureate level and $10 \%$ have advanced degrees. Table II gives some indication of level of education by grade level through the computation of an "education index" with values assigned shown in the scale.

\section{TABLE II}

EDUCATION INDEX BY GRADE

Scale:

1 = Some high school

2 = High school graduate

3 = Some college

4 = College graduate

5 = Post-graduate study

\begin{tabular}{lccccccc}
\hline & Total & GS 11 & GS 12 & GS 13 & GS 14 & GS 15 \\
\hline Index & 3.96 & 3.58 & 4.05 & 4.21 & 4.11 & 4.00 \\
Number & 114 & 33 & 37 & 28 & 9 & 7 \\
\hline
\end{tabular}


Table II indicates that the GS 13 has the greatest amount of formal education while the GS 11 has the least. This may be explained due to the fact that many employees reach their grade "peak" at GS 11 and go no further. GS 11 may be the top grade for many people lacking much education and those who show little promise of further advancement.

BPA executives with college degrees are most likely to have a Bachelor of Science degree. Ninety-one per cent hold the BS degree while only 98 hold a Bachelor of Arts degree. The degree awarded to the "average" college graduate was awarded in the late 1940s. Table III outlines the major subject studied for all those who have attended college:

\section{TABLE III}

MAJOR SUBJECTS STUDIED

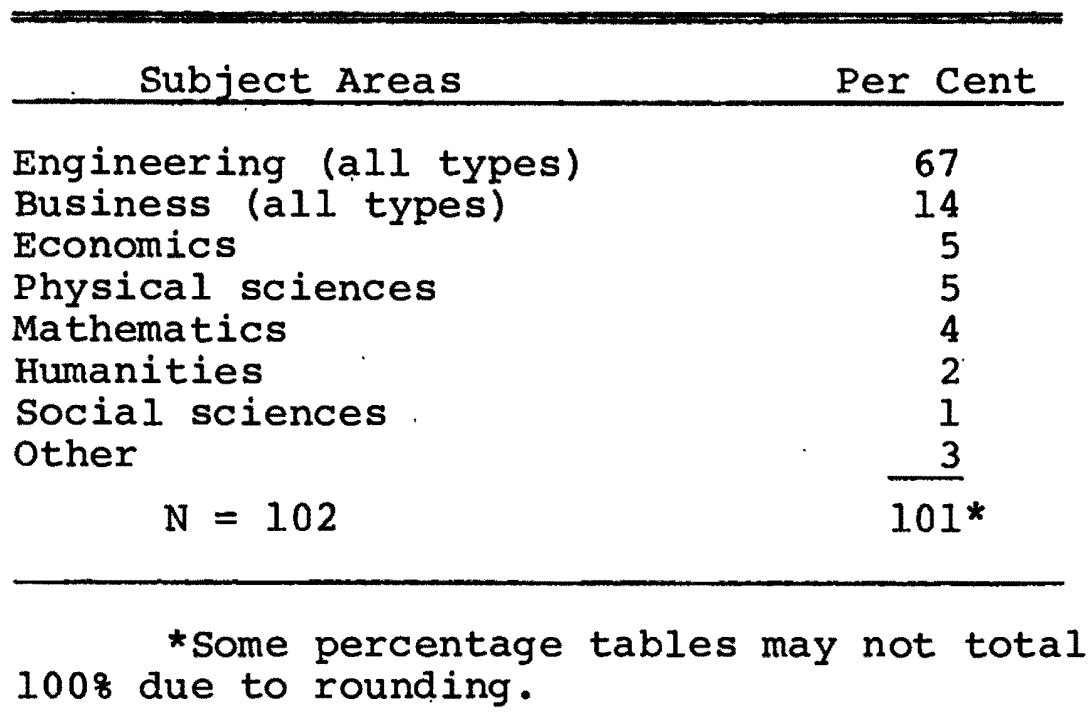

Table IV indicates the location and type of college attended for all those who attended college. Table V identifies 
the specific state university for those who attended Northwest state institutions. This data is thought to be important because it may offer clues as to trends in particular institutions or geographic areas that may serve as training grounds or as a báse for recruitment for BPA.

TABLE IV

LOCATION OF COLLEGE OR UNIVERSITY ATTENDED

Northwest State:College or University 62 Northwest Private College or University Non-Northwest State College or University

TABLE V

NORTHWEST STATE SCHOOLS ATTENDED

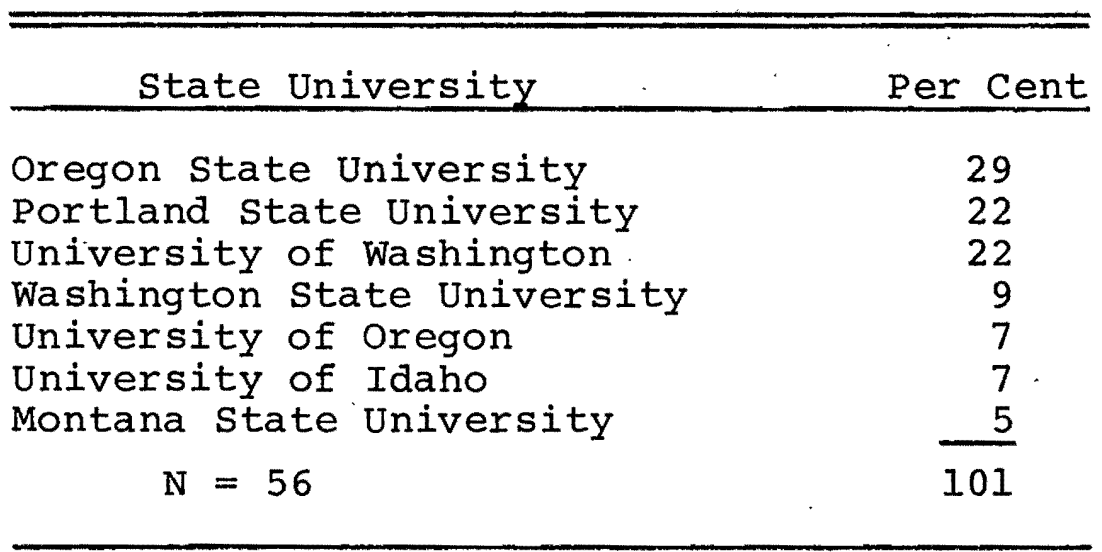


Each respondent to the questionnaire was asked to list all "career significant" employment held prior to beginning at BPA and to note the length of time employed. Table VI represents a necessarily rough attempt at digesting each response into a particular category of employment. The purpose of this information was to determine if any particular business or governmental agency was predominate in preBPA employment. The evidence in Table VI indicates that public and private power groups do not provide a significant training ground for BPA executives as might be expected.

TABLE VI

PRE-BPA EMPLOYMENT

\begin{tabular}{lc}
\hline \multicolumn{1}{c}{ Employment } & Per Cent \\
\hline Other Federal Agency & 23 \\
Military Service (non-career) & 22 \\
BPA First Employment & 19 \\
Commercial (small business) & 10 \\
Private Power Firm & 7 \\
Heavy Industry & 6 \\
Public Power & 4 \\
Electrical Manufacturing & 3 \\
Other & 7 \\
\multicolumn{1}{c}{ N 113} & 101 \\
\hline
\end{tabular}

Students of bureaucracy are interested not only in where personnel come from, but also in where they are going. While no particular business group feeds personnel to BPA, that does not mean that BPA is not a training ground for 
some other firm or agency. To get at this sort of information is difficult; however, a rough indicator of post-BPA mobility may be determined by simply asking the executives where they would go if they left BPA for any reason. Table VII details the responses to the following question: "If you were to leave BPA for any reason, for whom would you consider working?"

TABLE VII

FIRST PREFERENCE: POST-BPA EMPLOYMENT

\begin{tabular}{lr}
\hline \multicolumn{1}{c}{ First Preference } & Per Cent \\
\hline Another Federal Agency & 29 \\
Self-employment. & 17 \\
Commercial and Business & 10 \\
Engineering Consulting Firm. & 9 \\
Private Power Firm & 9 \\
Public Power Agency & 6 \\
Manufacturing Industry & 6 \\
Other . & 15 \\
$\quad \mathrm{~N}=82$ & 101 \\
\hline
\end{tabular}

Table VII is only a crude index of BPA executive mobility because it relies on supposition and preference rather than on hard data. However, there is little indication that any particular firm or job area uses BPA as its training ground. Tables VI and VII do indicate a considerable tendency toward coming from and staying with some federal agency. This trend may be due to the relative security and generous retirement and vacation benefits offered by federal 
employment. If the trends in Tables VI and VII are accurate, it may be surmised that there is some inter-agency mobility among the Northwest federal agencies. The implications of this finding could be far-reaching. For example, interagency cooperation and communication might be increased. On the other hand, perspectives fostered in one agency might thus be transferred and transplanted to another agency. Because an individual who leaves one agency would tend to have some peer-group attachment remain with that agency, there may be a reluctance to oppose or criticize the policy of the old agency. Thus, inter-agency mobility may somewhat offset the traditional inter-agency competition.

Another section of the questionnaire sought to determine the degree of intra-agency mobility. That is, to what extent do BPA executives transfer laterally into different types of jobs within the organization? Judging from descriptions of job position, GS levels, and length of time held, there is very little lateral transfer at BPA. Personnel tend to stay in one area as they advance in GS level. A typical case might be instructive. A GS 13 began at BPA as a GS 5 meter relay maintenance man. He has risen in grade to GS 13 and is now a foreman in a meter relay section. Such vertical ascendance is the rule rather than the exception at BPA. Except in some administrative fields, skills would seem to be difficult to transfer laterally. An engineer would not usually be an effective head of an accounting section and the 
accountant would make a poor sub-station operator. BPA's mission of marketing and transmitting power calls for special expertise to accomplish these goals. Unless the individual shows special flexibility, he is very likely to ascend the promotion ladder within that narrow field.

BPA came into existence in 1938 and only a small portion of the personnel in 1972 have been with BPA since its. inception. Each respondent was asked to state the date that he began work at BPA. Table VIII shows the percentages of personnel that began at BPA within certain time blocks. The table shows that growth in personnel has not been a smooth upward line. The 1ate 1940s and the early 1960s seem to be periods of special growth in numbers of personnel (at least those that still remain).

TABLE VIII

YEAR OF INITIAL EMPLOYMENT

(BY PER CENT)

\begin{tabular}{lc}
\hline \multicolumn{1}{c}{ Year } & Per Cent \\
\hline $1938-1940$ & 9 \\
$1941-45$ & 8 \\
$1946-50$ & 17 \\
$1951-55$ & 5 \\
$1956-60$ & 11 \\
$1961-65$ & 28 \\
$1966-70$ & 21 \\
$1971-72$ & 1 \\
$\mathrm{~N}=113$ & 100 \\
\hline
\end{tabular}


Many of the BPA executives noted that their careers had been interrupted or preceded by military service. The U.S. Civil Service Commission gives five and ten point veterans' preference bonus points which are added to scores on the civil'service examinations. Such a bonus can often mean the difference between gaining or losing a federal job, especially when competing with non-veterans. Table IX outlines the percentages of BPA executives who claimed five or ten point preferences. The table is based on information supplied from $B P A$ and is thus for the entire sample of 140 regardless of whether the individual responded to the questionnaire.

TABLE IX

PER CENT OF SAMPLE CLAIMING FIVE OR TEN POINT VETERANS' PREFERENCE

\begin{tabular}{lccccccc}
\hline & Total & GS 11 & GS 12 & GS 13 & GS 14 & GS 15 \\
\hline $\begin{array}{l}5 \text { or } 10 \text { point } \\
\text { preference }\end{array}$ & $65 \%$ & $55 \%$ & $66 \%$ & $62 \%$ & $83 \%$ & $83 \%$ \\
$N=140$ & & & & & & & \\
\hline
\end{tabular}

Table IX shows that a high percentage of BPA executives claim veterans' preference points and that the percentage generally increases--except for GS 13--with increase in GS level. The paucity of females among the executives at BPA may be due in part to the fact that veterans' preference 
points are overwhelmingly awarded to males. Females are awarded points only if they have served in the armed forces or are widows of veterans killed in the military.

The profile of BPA executives gives us some idea of what they are like, where they came from, and where they might go. But this profile is only a foundation from which to compare what they think. If training, education, and background are related to policy outcomes, we would expect to find some differences and similarities in attitudes and perceptions toward certain policy matters. It is to these considerations that the study now turns. 


\section{CHAPTER V}

\section{ATTITUDES AND PERCEPTIONS}

\section{INTRODUCTION}

The questionnaire asked several questions in an effort to determine what BPA executives think of their agency and its policies. The responses to these questions are important because they enable the observer to determine perceptions for the organization as a whole and to make comparisons between background variables for sub-groups. Most of the questions were open-ended; that is, the questions had no answers from which to select, thus requiring the respondent to write out his or her answer. Another section scaled differences in degree of agreement on several statements. The open-ended questions are presented first.

\section{OPEN-ENDED ATTITUDINAL DATA}

One effort at determining perceptions of the agency as a whole was a question that asked: "What group or groups benefit most from BPA policies?" Each individual was given four spaces in which to respond to the question with what is hoped to be an "insiders" viewpoint as to who or what gains from BPA's existence. Only the first group identified by each individual is recorded in Table $\mathrm{X}$ because responses 
dropped off sharply after the first choice.

TABLE X

PERCEPTIONS OF BENEFICIARIES

OF BPA POLICY

\begin{tabular}{lc}
\hline \multicolumn{1}{c}{ Group Identified } & Per Cent \\
\hline General Public & 39 \\
Public Power Utilities & 37 \\
Electro-Process/Industrial & 13 \\
Private Power Utilities & 5 \\
"Preference Customers" & 5 \\
Federal Agencies & 1 \\
Business & 1 \\
$\quad N=106$ & 101 \\
\hline
\end{tabular}

The responses on Table $\mathrm{x}$ require some interpretation. Although the general public was most often identified as the greatest beneficiary of BPA policy, that finding would be misleading until considered in context with the other responses. For example, the sum of the percentages of all the customers chosen for whom BPA shows preference (by law)-public power groups, 37\%; federal agencies, 1\%; and "preference customers," 5\%--totals $43 \%$. Another way to look at these results is that $61 \%$ of the respondents saw groups other than the general public as the primary beneficiary of BPA policies. Although the public may be perceived as the ultimate beneficiary of BPA policies, a significant percentage of BPA executives indicated that their first choice was something other than the general public. Perceptions of 
groups benefiting held remarkably constant when compared with GS level, age, and education.

Another open-ended question sought to find out what groups or individuals were perceived as having the most influence on BPA policy. It was hoped that responses would yield some indication of perceptions of outside support and clues as to BPA's interior power structure. Table XI lists the responses and percentages to the question: "From your perspective, which groups or individuals (both inside and outside of BPA) have the most influence on BPA policy?"

The responses in Table XI proved to be not only diverse but also somewhat surprising in the number of choices identified. Congress (18\%) was perceived as most influential, probably a reflection of the frustration directed toward the power of appropriation. Private power seems to be fairly equal in perceived influence with public power, yet public power was viewed as a far greater beneficiary of BPA policy in Table $x$. Other high positions in the agency.'s hierarchy were mentioned as having considerable influence, namely the Power Manager, the Chief Engineer, and the "top staff" who combined have nearly the perceived influence of the administrator. If influence is at least partly dependent on support offered, then no clear indication of BPA support emerges. Generally, there is no particular perception of influence that commands the great majority of opinion. 
TABLE XI

POLICY INELUENCE

\begin{tabular}{|c|c|c|c|}
\hline Group or Individual & $\begin{array}{c}\text { Per Cent } \\
\text { Ist } \\
\end{array}$ & & $\begin{array}{c}\text { Per Cent } \\
\text { 2nd }\end{array}$ \\
\hline Congress & 18 & & 9 \\
\hline BPA Administrator & 11 & & 7 \\
\hline Public power & 9 & & 10 \\
\hline Politics/politicians & 8 & & 4 \\
\hline Department of Interior & 8 & & 7 \\
\hline Private power & 7 & & 16 \\
\hline President/administration & 5 & & 3 \\
\hline Environmentalists & 4 & & 1 \\
\hline Power manager (BPA) & 4 & & 3 \\
\hline $\begin{array}{l}\text { Bonneville Regional Advisory } \\
\text { Council }\end{array}$ & 4 & & 3 \\
\hline General public & 4 & & 2 \\
\hline BPA top staff & 3 & & 8 \\
\hline Senator Jackson & 3 & & .0 \\
\hline Aluminum industry & 3 & & 4 \\
\hline "Customers" & 2 & . & 6 \\
\hline Joint Power Planning Council & 2 & & 1 \\
\hline Chief engineer/engineers & 1 & . & 1 \\
\hline Office of Management and Budget & 0 & & 4 \\
\hline Business & 1 & & 0 \\
\hline Other & 2 & & 11 \\
\hline $\mathrm{N}=100$ lst choice & & & \\
\hline $\mathrm{N}=95$ 2nd choice & 99 & & 100 \\
\hline
\end{tabular}


Because attitudes and perceptions may partly be a function of self-perception, a question was asked which was designed to determine perceptions of self-influence. Each respondent was given four choices--no influence, little influence, some influence, and much influence--to describe his perception of his influence with his supervisor. Table XII shows the results for the total sample and Tables XIII and XIV show differences in self-perception based on GS level and age through the use of a scale (shown on Table XII).

\section{TABLE XII}

PERCEPTIONS OF SELF-INFLUENCE : TOTAL SAMPLE

\begin{tabular}{ccc}
$\begin{array}{c}\text { Value : } \\
\text { Assigned }\end{array}$ & \\
\hline 1 & No influence & Per Cent \\
2 & Little influence & 1 \\
3 & Some influence & 12 \\
4 & Much influence & $\frac{23}{100}$ \\
& $N=111$ & \\
\hline
\end{tabular}

TABLE XIII

SELF-INFLUENCE INDEX BY GS LEVEL

Total

Sample

GS 11

GS 12

GS 13

GS 14

GS 15

3.13

2.93

3.05

3.21

3.44

3.14

$\mathrm{N}=111$

$\mathrm{N}=30$

$\mathrm{N}=37$

$\mathrm{N}=28$

$\mathrm{N}=9$

$\mathrm{N}=7$ 
TABLE XIV

SELF-INFLUENCE INDEX BY AGE

\begin{tabular}{lllll}
\hline $20-29$ & $30-39$ & $40-49$ & $50-59$ & $60-69$ \\
Years & Years & Years & Years & \begin{tabular}{l} 
Years \\
\hline 2.83
\end{tabular} \\
\hline $\mathrm{N}=6$ & $\mathrm{~N}=31$ & $\mathrm{~N}=28$ & 2.93 & 3.25 \\
& & $\mathrm{~N}=28$ & $\mathrm{~N}=30$ & $\mathrm{~N}=12$
\end{tabular}

The greatest concentration of perceptions of selfinfluence lies in the "some influence" range. Also, perceptions of influence generally increase with grade (except GS 15, surprisingly) and age (except those in their 50s). These deviations are difficult to explain because they deal with perceptions of the self and not of fact. However, one possible explanation is that the GS 15 may not have as much influence as he expected to come with his high grade. He may feel that the younger GS $13 \mathrm{~s}$ and $14 \mathrm{~s}$ are threatening his position. Also, those who supervise GS $15 \mathrm{~s}$ may not be as open to subordinate influence as lower grade officials. The index of those in their 50 s may be lowered by those in lower grades who are facing retirement in the near future and see little chance for further promotion.

To better ascertain executive attitudes toward certain specific issues at $B P A$, eleven attitudinal statements were included in the questionnaire. The respondent was asked to circle one of five numbers to express his degree of agreement 
or disagreement with the statement. In this way, a mean could be computed which is very similar to a grade point average. The statements were prefaced with the following instructions :

This section of the questionnaire is designed to determine degree of agreement or disagreement on several statements. Please circle the number following the statement that most nearly conforms with your views on the issue.

$$
\begin{aligned}
\text { Scale: } & \\
1 & =\text { Strongly agree } \\
2 & =\text { Mildly agree } \\
3 & =\text { Neutral } \\
4 & =\text { Mildly disagree } \\
5 & =\text { Strongly disagree }
\end{aligned}
$$

This numerical system permitted easy computation of mean scores for different variables. Each statement will be dealt with separately and correlated with GS level, age, and education variables. The specific education variables compared are: those with no degree versus those with four year degrees and those with advanced degrees; those with a background in engineering studies and those with little or no engineering education; those with Bachelor of Arts degrees versus those with Bachelor of Science degrees; and, those with a background in business studies versus all others. Statements dealing with environment, growth, and conservation of energy will be treated as one unit and statements dealing with the role of the agency will be treated as a separate unit. 
III. ENVIRONMENTAL ATTITUDES

The sudden upsurge of public interest in environmental matters during the late 1960s caught many groups--including BPA--by surprise. Suddenly, BPA was forced not only to reevaluate its policies relating to the environment, but also to defend its basic role in the life of the Northwest. Policies that had gone almost unchallenged for more than thirty years became the target of scrutiny by the press and environmental groups.

Two fundamentally opposing points of view. on energy policy were expressed. The environmentalists generally pointed out that all known methods of generating and transmitting electric energy, were somewhat damaging to the environment. Therefore, they argued, energy use and generation should be re-evaluated in terms of what was really necessary; thus, emphasis should be moved from encouraging use to encouraging conservation of energy. In addition, environmental activists argued that an increasing population was bound to cause increased demand which would cause a need for more generating capacity in an escalating fashion. Underlying the environmentalist viewpoint was the belief that unbridled economic growth could be the end of their perception of a high quality of life in the Northwest if no limits were imposed on new industry, business, and population. The environmentalists realized that if they 
could gain control of the energy system, they could largely control growth. The criticisms of BPA had this belief clearly in mind.

A well organized and vociferous counter-attack to the environmentalist viewpoint came from public and private power agencies, industry, the business community, and BPA itself. These forces generally agreed that environmental damage should be avoided where possible, but disagreed vigorously on the contention that power supply should be limited. Energy demand, from their point of view, was a reflection of consumer demand that in turn mirrored the increasing standard of living. To limit energy supply, they argued, would stagnate man's quest for an ever more comfortable existence. They supported the Hydro-Thermal program as an acceptable plan to provide for future energy demand, while acknowledging that some environmental damage was unavoidable. They rejected the idea of limiting growth as an unacceptable restraint on man's intellect. They further attacked the environmentalists as representing no one but their own small interest groups.

BPA personnel are forced to evaluate the thrust and implications of both the environmentalist and power-advocate positions. Six of the eleven attitudinal statements are geared toward determining feelings on issues pertinent to the environmental questions: 
Statement A: Environmentalists' Concerns

"The environmentalists generally have become too concerned with their narrow goals and not concerned enough with the energy requirements of the whole society." This statement is designed to be a rough index of attitudes toward environmentalists when the issue is put against "energy requirements." Recent federal directives have motivated BPA to put emphasis on minimizing environmental damage as it continued to market and transmit power. This policy has undoubtedly put some stress on engineers and planners who must adapt their designs and long-range plans to meet the environmental guidelines. New transmission tower designs, narrower right-of-ways, environmental impact statements, and sub-station beautification are only a few of the efforts going on to conform to the new environmental emphasis. However, the conflict between BPA and the environmentalists is quite clear. BPA fully intends to continue to meet what it considers to be the insatiable demand for energy while the environmentalist argues that any dam, nuclear power plant, right-of-way, sub-station, or transmission tower will be somewhat damaging to the natural environment. The issue then turns into an argument about what energy demand and construction is actually necessary. In addition, response to the statement may give indications as to the degree of dedication that BPA executives have toward the environmental requirements. 
TABLE XV

\section{ENVIRONMENTALISTS' CONCERNS}

"The environmentalists generally have become too concerned with their narrow goals and not concerned enough with the energy requirements of the whole society."

$\begin{array}{ccccc}1 & 2 & 3 & 4 & 5 \\ \begin{array}{c}\text { strongly } \\ \text { agree }\end{array} & \begin{array}{l}\text { mildly } \\ \text { agree }\end{array} & \text { neutral } & \text { mildly } & \text { strongly } \\ & & & \text { disagree } & \text { disagree }\end{array}$

\begin{tabular}{|c|c|c|c|c|c|c|c|c|c|c|c|}
\hline & \multirow[b]{2}{*}{ Total } & \multicolumn{5}{|c|}{ GS Leve I } & \multicolumn{5}{|c|}{ Age } \\
\hline & & 11 & 12 & 13 & 14 & 15 & $\overline{20 s}$ & $30 \mathrm{~s}$ & $40 s$ & $50 \mathrm{~s}$ & $60 \mathrm{~s}$ \\
\hline Mean & 2.27 & 2.63 & 2.49 & 1.86 & 2.11 & 1.43 & 3.43 & 2.87 & 1.96 & 1.93 & 1.75 \\
\hline $\mathrm{N}^{*}$ & 113 & 32 & 37 & 28 & 9 & 7 & 7 & 31 & 28 & 30 & 12 \\
\hline
\end{tabular}

\begin{tabular}{|c|c|c|c|c|c|c|c|c|c|}
\hline & \multicolumn{9}{|c|}{ Education } \\
\hline & $\begin{array}{c}\text { No } \\
\text { Degree } \\
\end{array}$ & $\begin{array}{l}\text { All w/ } \\
\text { Degree }\end{array}$ & $\begin{array}{c}\text { Adv. } \\
\text { Degree }\end{array}$ & Eng** & $\begin{array}{l}\text { Non- } \\
\text { Eng. }\end{array}$ & $\begin{array}{c}\text { BS } \\
\text { Degree } \\
\end{array}$ & $\begin{array}{c}B A \\
\text { Degree }\end{array}$ & Bus. $* * *$ & $\begin{array}{l}\text { Non- } \\
\text { Bus. }\end{array}$ \\
\hline Mean & 2.22 & 2.29 & 2.7 & 2.28 & 2.18 & 2.25 & 2.38 & 1.36 & 2.40 \\
\hline $\mathrm{N}$ & 23 & 90 & 10 & 67 & 34 & 81 & 8 . & 14 & 99 \\
\hline
\end{tabular}

\footnotetext{
$*_{\mathrm{N}}=$ Number

$* *$ Eng. = Engineer

$\star * *$ Bus. $=$ Business
} 
Statement B: Aluminum Plants

"From hindsight it was a mistake to encourage the aluminum reduction plants to come to the Northwest." This statement reflects much popular sentiment that were it not for aluminum mills, there would be no energy shortage in the future. But the position taken by many at BPA is that the aluminum mills have been a reliable and predictable purchaser of power that otherwise might have been wasted generating potential. Also, some at BPA argue that aluminum mills have been a great boon to the Northwest economy. The other side of the argument is that what was once surplus energy will soon be needed for preference customers, and that BPA has no statutory obligation to continue sales of cheap energy to aluminum mills. This side also argues that BPA has no obligation to attract new business or to insure the expansion of present plants. The issue often generates into an emotional debate with both sides using only those facts that tend to sustain their conclusions.

The statement was designed in such a way that a BPA executive could agree or disagree with the statement and know that his opinion had the benefit of retrospect. 
TABLE XVI

\section{ALUMINUM PLANTS}

"From hindsight, it was a mistake to encourage the aluminum reduction plants to come to the Northwest."

$\begin{array}{ccccc}1 & 2 & 3 & 4 & 5 \\ \begin{array}{c}\text { strongly } \\ \text { agree }\end{array} & \begin{array}{l}\text { mildly } \\ \text { agree }\end{array} & \text { neutral } & \text { disagree } & \text { disagree }\end{array}$

\begin{tabular}{|c|c|c|c|c|c|c|c|c|c|c|c|}
\hline & \multirow[b]{2}{*}{ Total } & \multicolumn{5}{|c|}{ GS Level } & \multicolumn{5}{|c|}{ Age } \\
\hline & & 11 & 12 & 13 & 14 & 15 & $20 \mathrm{~s}$ & $30 \mathrm{~s}$ & $40 \mathrm{~s}$ & $50 \mathrm{~s}$ & $60 \mathrm{~s}$ \\
\hline Mean & 3.9 & 3.58 & 3.75 & 4.29 & 4.44 & 4.00 & 3.86 & 3.42 & 4.14 & 3.9 & 4.33 \\
\hline $\mathrm{N}$ & 113 & 33 & 36 & 28 & 9 & 7 & 7 & 31 & 29 & 30 & 12 \\
\hline
\end{tabular}

\begin{tabular}{|c|c|c|c|c|c|c|c|c|c|}
\hline & \multicolumn{9}{|c|}{ Education } \\
\hline & $\begin{array}{c}\text { No } \\
\text { Degree } \\
\end{array}$ & $\begin{array}{l}\text { All w/ } \\
\text { Degree }\end{array}$ & $\begin{array}{c}\text { Adv. } \\
\text { Degree }\end{array}$ & Eng. & $\begin{array}{l}\text { Non- } \\
\text { Eng. }\end{array}$ & $\begin{array}{c}\text { BS } \\
\text { Degree } \\
\end{array}$ & $\begin{array}{c}\mathrm{BA} \\
\text { Degree }\end{array}$ & Bus. & $\begin{array}{l}\text { Non- } \\
\text { Bus. }\end{array}$ \\
\hline Mean & 4.13 & 3.84 & 4.30 & 4.10 & 3.65 & 3.91 & 3.5 & 3.64 & 3.89 \\
\hline $\mathrm{N}$ & 24 & 89 & 10 & 67 & 34 & 80 . & 8 & 14 & 99 \\
\hline
\end{tabular}


Statement C: Necessity of Growth

"The continued growth of business and industry is necessary if we are to maintain the high standard of living that we enjoy here in the Northwest." The preceding statement is perhaps the most vague of all the attitudinal tests. "High standard of living" is not defined or distinguished from quality of life. Neither was "continued growth" separated from "just enough growth" or "perpetual growth." At any rate, the statement is designed to offer a gauge of the extent to which BPA executives see growth as necessary or in conflict with some notion of quality of life. Again, the conflict between some environmental and economic considerations is brought into focus. Those who argue that growth and environment are incompatible are contrasted with those who see growth as a function of consumer demand which cannot or should not be limited. Despite the impreciseness of the statement, only two respondents declined to scale their opinions. 
TABLE XVII

\section{NECESSITY OF GROWTH}

"The continued growth of business and industry. is necessary if we are to maintain the high standard of living that we enjoy here in the Northwest."

$\begin{array}{ccccc}1 & 2 & 3 & 4 & 5 \\ \begin{array}{c}\text { strongly } \\ \text { agree }\end{array} & \begin{array}{l}\text { mildly } \\ \text { agree }\end{array} & \text { neutral } & \begin{array}{c}\text { mildly } \\ \text { disagree }\end{array} & \begin{array}{c}\text { strongly } \\ \text { disagree }\end{array}\end{array}$

\begin{tabular}{|c|c|c|c|c|c|c|c|c|c|c|c|}
\hline & \multirow[b]{2}{*}{ Total } & \multicolumn{5}{|c|}{ GS Level } & \multicolumn{5}{|c|}{ Age } \\
\hline & & 11 & 12 & 13 & 14 & 15 & $20 s$ & $30 s$ & $40 s$ & $50 \mathrm{~s}$ & $60 \mathrm{~s}$ \\
\hline Mean & 2.46 & 2.29 & 2.86 & 2.25 & 2.22 & 2.14 & 2.83 & 3.16 & 2.14 & 2.30 & 2.00 \\
\hline $\mathrm{N}$ & 112 & 31 & 37 & 28 & 9 & 7 & 7 & 31 & 28 & 30 & 12 \\
\hline
\end{tabular}

\begin{tabular}{|c|c|c|c|c|c|c|c|c|c|}
\hline & \multicolumn{9}{|c|}{ Education } \\
\hline & $\begin{array}{c}\text { No } \\
\text { Degree }\end{array}$ & $\begin{array}{l}\text { All w/ } \\
\text { Degree }\end{array}$ & $\begin{array}{c}\text { Adv. } \\
\text { Degree }\end{array}$ & Eng. & $\begin{array}{l}\text { Non- } \\
\text { Eng. }\end{array}$ & $\begin{array}{c}\text { BS } \\
\text { Degree } \\
\end{array}$ & $\begin{array}{c}\mathrm{BA} \\
\text { Degree }\end{array}$ & Bus. & $\begin{array}{l}\text { Non- } \\
\text { Bus. }\end{array}$ \\
\hline Mean & 2.13 & 2.54 & 2.50 & 2.56 & 2.29 & 2.59 & 2.0 & 1.86 & 2.55 \\
\hline $\mathrm{N}$ & 23 & 89 & 10 & 68 & 34 & 81 & 8 & 14 & 98 \\
\hline
\end{tabular}


Statement D: Reduce Economic Expansion

"BPA should take a part in reducing the rate of economic expansion in the Northwest with policies that restrict availability of power." This statement should appeal only to those who think that economic growth can be and should be limited and that BPA is the proper instrument to make the necessary political choices. Because of these restrictions, the statement is of only limited value. For example, a respondent may believe that growth should be restricted, but that BPA should not be the agency to decide who and how much should be restricted. Such a person would then be forced to disagree with the statement. Some environmentalists see political control over energy as one of the most effective methods of containing growth while protecting the environment. Again, the conflict between environmentalists and expansionists is brought into the open. The results follow on Table XVIII. 
TABLE XVIII

REDUCE ECONOMIC EXPANSION

"BPA should take a part in reducing the rate of economic expansion in the Northwest with policies that restrict availability of power."

$\begin{array}{ccccc}1 & 2 & 3 & 4 & 5 \\ \begin{array}{c}\text { strongly } \\ \text { agree }\end{array} & \begin{array}{l}\text { mildly } \\ \text { agree }\end{array} & \text { neutral } & \begin{array}{c}\text { mildly } \\ \text { disagree }\end{array} & \begin{array}{l}\text { strongly } \\ \text { disagree }\end{array}\end{array}$

\begin{tabular}{|c|c|c|c|c|c|c|c|c|c|c|c|}
\hline & \multirow[b]{2}{*}{ Total } & \multicolumn{5}{|c|}{ GS Level } & \multicolumn{5}{|c|}{ Age } \\
\hline & & 11 & 12 & 13 & 14 & 15 & $20 s$ & $30 s$ & $40 s$ & $50 \mathrm{~s}$ & $60 s$ \\
\hline Mean & 3.87 & 3.63 & 3.73 & 4.25 & 3.89 & 4.29 & 3.33 & 3.61 & 4.07 & 4.27 & 3.67 \\
\hline $\mathrm{N}$ & 113 & 32 & 37 & 28 & 9 & 7 & 7 & 31 & 29 & 30 & 12 \\
\hline
\end{tabular}

\begin{tabular}{lcccccccccc}
\hline & \multicolumn{10}{c}{ Education } \\
\cline { 2 - 9 } & $\begin{array}{c}\text { No } \\
\text { Degree }\end{array}$ & $\begin{array}{c}\text { A11 w/ } \\
\text { Degree }\end{array}$ & $\begin{array}{c}\text { Adv. } \\
\text { Degree }\end{array}$ & Eng. & $\begin{array}{c}\text { Non- } \\
\text { Eng. }\end{array}$ & $\begin{array}{c}\text { BS } \\
\text { Degree }\end{array}$ & $\begin{array}{c}\text { BA } \\
\text { Degree }\end{array}$ & Bus. & $\begin{array}{c}\text { Non- } \\
\text { Bus. }\end{array}$ \\
\hline \multirow{2}{*}{ Mean } & 4.04 & 3.83 & 3.9 & 3.91 & 3.85 & 3.81 & 4.0 & 4.29 & 3.80 \\
N & 24 & 89 & 10 & 68 & 34 & 81 & 8 & 14 & 99 \\
\hline
\end{tabular}


Statement E: Conservation of Energy

"BPA should become more actively involved in the promotion of conservation of electric energy." As noted earlier, BPA gives only minimal support to energy conservation. But the question is asked whether BPA executives believe that enough is being done and what new direction might be preferred. It should be added as a note of reservation that to someone seriously interested in conservation of energy, no effort would seem too great. Becoming "more actively involved" does not indicate just how involved the respondent intends.

There is some sentiment (detected in personal interviews) at $B P A$ which rather patronizingly accepts the idea that energy conservation is important. But at the same time, some of these individuals point to a study done by an engineer which alleges that if all electric toothbrushes were eliminated, the need for the next nuclear generating plant would only be delayed by a few days. This attitude expresses the belief that the consumer will not do without conveniences and that to attempt to conserve in consumer use is somewhat of a wasted effort. But the toothbrush adage indicates that there is little seriousness in trying to use technology to conserve energy in such areas as insulation and heating. But Table XIX shows that such attitudes are not dominant. 
TABLE XIX

CONSERVATION OF ENERGY

"BPA should become more actively involved in the promotion of conservation of electric energy."

$\begin{array}{ccccc}1 & 2 & 3 & 4 & 5 \\ \begin{array}{c}\text { strongly } \\ \text { agree }\end{array} & \begin{array}{l}\text { mildly } \\ \text { agree }\end{array} & \text { neutral } & \begin{array}{c}\text { mildly } \\ \text { disagree }\end{array} & \begin{array}{c}\text { strongly } \\ \text { disagree }\end{array}\end{array}$

\begin{tabular}{|c|c|c|c|c|c|c|c|c|c|c|c|}
\hline & \multirow[b]{2}{*}{ Total } & \multicolumn{5}{|c|}{ GS Level } & \multicolumn{5}{|c|}{ Age } \\
\hline & & 11 & 12 & 13 & 14 & 15 & $20 \mathrm{~s}$ & $30 \mathrm{~s}$ & $40 s$ & $50 s$ & $60 s$ \\
\hline Mean & 2.20 & 2.27 & 2.03 & 2.42 & 2.0 & 2.14 & 2.29 & 2.26 & 2.36 & 2.34 & 2.08 \\
\hline $\mathrm{N}$ & 112 & 33 & 37 & 26 & 9 & 7 & 7 & 31 & 28 & 29 & 12 \\
\hline
\end{tabular}

Education

\begin{tabular}{|c|c|c|c|c|c|c|c|c|c|}
\hline & $\begin{array}{c}\text { No } \\
\text { Degree }\end{array}$ & $\begin{array}{l}\text { Al1 w/ } \\
\text { Degree }\end{array}$ & $\begin{array}{c}\text { Adv. } \\
\text { Degree }\end{array}$ & Eng. & $\begin{array}{l}\text { Non- } \\
\text { Eng. }\end{array}$ & $\begin{array}{c}\text { BS } \\
\text { Degree }\end{array}$ & $\begin{array}{c}\mathrm{BA} \\
\text { Degree }\end{array}$ & Bus. & $\begin{array}{l}\text { Non- } \\
\text { Bus. }\end{array}$ \\
\hline Mean & 2.22 & 2.19 & 1.9 & 2.24 & 2.21 & 2.23 & 2.0 & 2.50 & 2.19 \\
\hline $\mathrm{N}$ & 23 & 89 & 10 & 67 & 34 & 80 & 8 & 14 & 99 \\
\hline
\end{tabular}


Environmental Section Summary

The responses to the preceding statements are generally self-explanatory. However, a brief summary of the environmentally oriented statements is in order. It is possible to generalize from the statements that BPA executives are largely skeptical of the goals and claims of the environmental groups. An exception seems to be the issue of promoting conservation of energy. Here, BPA executives and environmentalists would agree that more needs to be done to promote such conservation. (More will be said of this observation in the discussion chapter.) At any rate, interesting and rather definite patterns of attitudes have been shown on environmental issues. The study now turns to an analysis of attitudes shown on the functional role of BPA.

IV. FUNCTIONAL ROLE

Several statements were included in the questionnaire with the intent of determining attitudes on certain policies, roles, and related issues. While attitudes on specific issues are useful, the perception of the organization and its role by those in it may provide important clues as to which areas will receive emphasis or the lack of it. Additionally, examination of attitudes may give information on the static or dynamic nature of the agency. That is, has the perception or the agency's role changed over time when compared to historic trends? The following statements 
attempt to provide information on such matters. Because of the diverse nature of the statements, a summary will be delayed until the discussion chapter.

Statement F: Power Shortages

"BPA has the responsibility to do what it can to prevent a power shortage in the Northwest." This statement was designed to determine the degree with which BPA executives accepted the non-statutory role of preventing power shortages. Since BPA has in fact long been involved in attempting to prevent such shortages, the statement in reality seeks to investigate the degree with which the perceived "responsibility" has permeated the agency. 
TABLE XX

\section{POWER SHORTAGES}

"BPA has the responsibility to do what it can to prevent a power shortage in the Northwest."

$\begin{array}{ccccc}1 & 2 & 3 & 4 & 5 \\ \begin{array}{c}\text { strongly } \\ \text { agree }\end{array} & \begin{array}{l}\text { mildly } \\ \text { agree }\end{array} & \text { neutral } & \begin{array}{c}\text { mildly } \\ \text { disagree }\end{array} & \begin{array}{l}\text { strongly } \\ \text { disagree }\end{array}\end{array}$

\begin{tabular}{|c|c|c|c|c|c|c|c|c|c|c|c|}
\hline & \multirow[b]{2}{*}{ Tota 1} & \multicolumn{5}{|c|}{ GS Level } & \multicolumn{5}{|c|}{ Age } \\
\hline & & 11 & 12 & 13 & 14 & 15 & $20 \mathrm{~s}$ & $30 \mathrm{~s}$ & $40 s$ & $50 \mathrm{~s}$ & $60 s$ \\
\hline Mean & 1.39 & 1.21 & 1.51 & 1.28 & 1.66 & 1.71 & 1.00 & 1.67 & 1.28 & 1. 33 & 1.42 \\
\hline $\mathrm{N}$ & 114 & 33 & 37 & 28 & 9 & 7 & 7 & 31 & 29 & 30 & 12 \\
\hline
\end{tabular}

\begin{tabular}{|c|c|c|c|c|c|c|c|c|c|}
\hline & \multicolumn{9}{|c|}{ Education } \\
\hline & $\begin{array}{c}\text { No } \\
\text { Degree } \\
\end{array}$ & $\begin{array}{l}\text { All w/ } \\
\text { Degree }\end{array}$ & $\begin{array}{c}\text { Adv. } \\
\text { Degree }\end{array}$ & Eng. & $\begin{array}{l}\text { Non- } \\
\text { Eng. }\end{array}$ & $\begin{array}{c}\text { BS } \\
\text { Degree } \\
\end{array}$ & $\begin{array}{c}\text { BA } \\
\text { Degree } \\
\end{array}$ & Bus. & $\begin{array}{l}\text { Non- } \\
\text { Bus. }\end{array}$ \\
\hline Mean & 1.29 & 1.42 & 1.50 & 1.50 & 1.26 & 1.47 & 1.00 & 1.00 & 1.45 \\
\hline $\mathrm{N}$ & 24 & 90 & 10 & 68 & 34 & 81 & 8 & .14 & 100 \\
\hline
\end{tabular}


Statement G: Policy Disagreement

"Any BPA employee can air his disagreement on policy matters without fear of formal or informal pressures being brought against him." The preceding statement was intended to determine how "open" BPA appears to those who work there and to see if significant differences of opinion appeared for various sub-groups. Knowing the perceptions of employees on this issue is important because it may offer a clue as to why policy is often so difficult to challenge or change. If those who disagree with existing policy become reluctant to express their dissatisfaction, then policy may tend to be self-perpetuating. Response to the statement was varied and showed considerable divergence of opinion on the issue, as shown in Table XXI.

TABLE XXI

STATEMENT G PERCENTAGE SPREAD

$\begin{array}{lr}\text { Strongly agree } & 12 \% \\ \text { Mildly agree } & 32 \% \\ \text { Neutral } & 20 \% \\ \text { Mildly disagree } & 22 \% \\ \text { Strongly disagree } & 14 \% \\ & 100 \%\end{array}$


TABLE XXII

POLICY DISAGREEMENT

"Any BPA employee can air his disagreement on policy matters without fear of formal or informal pressures being brought against him."

$\begin{array}{ccccc}1 & 2 & 3 & 4 & 5 \\ \text { strongly } & \begin{array}{l}\text { mildly } \\ \text { agree }\end{array} & \text { neutral } & \text { mildly } & \text { strongly } \\ \text { agree } & & & \text { disagree } & \text { disagree }\end{array}$

\begin{tabular}{|c|c|c|c|c|c|c|c|c|c|c|c|}
\hline & \multirow[b]{2}{*}{ Total } & \multicolumn{5}{|c|}{ GS Level } & \multicolumn{5}{|c|}{ Age } \\
\hline & & 11 & 12 & 13 & 14 & 15 & $20 s$ & $30 \mathrm{~s}$ & $40 s$ & $50 s$ & $60 s$ \\
\hline Mean & 2.95 & 3.03 & 3.22 & 2.93 & 2.22 & 3.17 & 3.29 & 3.48 & 2.71 & 2.8 & 2.58 \\
\hline $\mathrm{N}$ & 113 & 33 & 37 & 28 & 9 & 6 & 7 & 31 & 28 & 30 & 12 \\
\hline
\end{tabular}

\begin{tabular}{|c|c|c|c|c|c|c|c|c|c|}
\hline & \multicolumn{9}{|c|}{ Education } \\
\hline & $\begin{array}{c}\text { No } \\
\text { Degree } \\
\end{array}$ & $\begin{array}{l}\text { All w/ } \\
\text { Degree }\end{array}$ & $\begin{array}{c}\text { Adv. } \\
\text { Degree } \\
\end{array}$ & Eng. & $\begin{array}{l}\text { Non- } \\
\text { Eng. }\end{array}$ & $\begin{array}{c}\text { BS } \\
\text { Degree } \\
\end{array}$ & $\begin{array}{c}\mathrm{BA} \\
\text { Degree } \\
\end{array}$ & Bus. & $\begin{array}{l}\text { Non- } \\
\text { Bus. }\end{array}$ \\
\hline Mean & 2.42 & 3.10 & 2.90 & 2.90 & 3.21 & 3.06 & 3.25 & 2.93 & 2.95 \\
\hline $\mathrm{N}$ & 24 & 89 & 10 & 67 & 34 & 80 & 8 & 14 & 99 \\
\hline
\end{tabular}


Statement $\mathrm{H}$ : Power Contracts

"Power contracts with private power utilities should be cancelled if such action is necessary to insure adequate electrical energy for public power groups." This statement was designed specifically to determine if a "public utility consciousness" exists at BPA. That is, do BPA executives believe that BPA is itself a utility that sells power to public and private utilities, and, as a utility, it should not be able to discriminate as to whom it sells that power? Regular utilities have a responsibility to sell their services to all within their monopoly areas without discrimination. Yet, if such an attitude exists at BPA, a conflict immediately; arises with the BPA Act. The Act specifically sets the following priorities for power consumption: public utilities, PUDs, cooperatives, rural and domestic consumers, and federal agencies. No mention is made of private utilities except to say that their contracts may be cancelled if necessary. The conflict is clear. The BPA Act dictates that the agency must cancel power contracts with private utilities if the power is needed to satisfy public groups. But, if BPA executives perceive a public utility responsibility, they will tend to disagree with the statement. 
TABLE XXIII

\section{STATEMENT H PERCENTAGE SPREAD}

$\begin{array}{ll}\text { Strongly agree } & 22 \% \\ \text { Mildly agree } & 19 \% \\ \text { Neutral } & 20 \% \\ \text { Mildly disagree } & 20 \% \\ \text { Strongly disagree } & 18 \% \\ & 99 \%\end{array}$

\section{TABLE XXIV}

POWER CONTRACTS

"Power contracts with private utilities should be cancelled if such action is necessary to insure adequate electrical energy for public power groups."

$\begin{array}{ccccc}1 & 2 & 3 & 4 & 5 \\ \begin{array}{c}\text { strongly } \\ \text { agree }\end{array} & \begin{array}{l}\text { mildly } \\ \text { agree. }\end{array} & \text { neutral } & \text { mildly } & \text { strongly } \\ & & & \text { disagree } & \text { disagree }\end{array}$

\begin{tabular}{|c|c|c|c|c|c|c|c|c|c|c|c|}
\hline & \multirow[b]{2}{*}{ Total } & \multicolumn{5}{|c|}{ GS Leve I } & \multicolumn{5}{|c|}{ Age } \\
\hline & & 11 & 12 & 13 & 14 & 15 & $20 \mathrm{~s}$ & $30 s$ & $40 s$ & $50 \mathrm{~s}$ & $60 \mathrm{~s}$ \\
\hline Mean & 2.94 & 2.94 & 3.27 & 2.86 & 2.88 & 1.57 & 3.00 & 3.10 & 2.93 & 2.73 & 2.75 \\
\hline $\mathrm{N}$ & 112 & 32 & 37 & 28 & 8 & 7 & 7 & 31 & 27 & 30 & 12 \\
\hline
\end{tabular}

\begin{tabular}{|c|c|c|c|c|c|c|c|c|c|}
\hline & \multicolumn{9}{|c|}{ Education } \\
\hline & $\begin{array}{c}\text { No } \\
\text { Degree } \\
\end{array}$ & $\begin{array}{l}\text { All w/ } \\
\text { Degree }\end{array}$ & $\begin{array}{c}\text { Adv. } \\
\text { Degree }\end{array}$ & Eng. & $\begin{array}{l}\text { Non- } \\
\text { Eng. }\end{array}$ & $\begin{array}{c}\text { BS } \\
\text { Degree } \\
\end{array}$ & $\begin{array}{c}\text { BA } \\
\text { Degree } \\
\end{array}$ & Bus. & $\begin{array}{l}\text { Non- } \\
\text { Bus. }\end{array}$ \\
\hline Mean & 2.74 & 2.99 & 3.40 & 2.88 & 3.06 & 3.08 & 2.38 & 3.57 & 2.85 \\
\hline $\mathrm{N}$ & 23 & 89 & 10 & 67 & 34 & 80 & 8 & 14 & 98 \\
\hline
\end{tabular}


Statement I: Compatibility of Function

"Marketing power and promoting the conservation of power are compatible functions for BPA." The point at issue in this statement is whether an agency whose central purpose has been the promotion of the use of electric energy can accommodate a program where conservation of power is encouraged. While BPA has no profit motive (any excess income over amortization costs for dams and construction reverts to the Treasury), it must meet its obligations through the sale of power. To encourage the conservation of power might reduce BPA's sales or antagonize some of BPA's customers. Thus, while BPA warns of an impending power crisis, it has no active program to promote energy conservation except for a few executives who give speeches to that effect to interested community groups. BPA has taken the initiative in solving other power problems that transcend the abilities of local utilities to handle, but it has taken no initiative on energy conservation. If such a program is attempted in the future, its success could well depend on the attitudes toward it by BPA executives. Table XXV outlines the attitudes toward the statement. 
TABLE XXV

COMPATIBILITY OF FUNCTIONS

"Marketing power and promoting the conservation of power are compatible functions for BPA."

$\begin{array}{ccccc}1 & 2 & 3 & 4 & 5 \\ \begin{array}{c}\text { strongly } \\ \text { agree }\end{array} & \begin{array}{l}\text { agree } \\ \text { agree }\end{array} & \text { neutral } & \text { mildly } & \text { strongly } \\ & & & \text { disagree } & \text { disagree }\end{array}$

\begin{tabular}{|c|c|c|c|c|c|c|c|c|c|c|c|}
\hline & \multirow[b]{2}{*}{ Total } & \multicolumn{5}{|c|}{ GS Level } & \multicolumn{5}{|c|}{ Age } \\
\hline & & 11 & 12 & 13 & 14 & 15 & $20 \mathrm{~s}$ & $30 s$ & $40 s$ & $50 s$ & $60 \mathrm{~s}$ \\
\hline Mean & 1.66 & 1.66 & 1.59 & 1.78 & 1.89 & 1.29 & 2.14 & 1.61 & 1.50 & 1.76 & 1.83 \\
\hline $\mathrm{N}$ & 112 & 32 & 37 & 27 & 9 & 7 & 7 & 31 & 28 & 29 & 12 \\
\hline
\end{tabular}

\begin{tabular}{|c|c|c|c|c|c|c|c|c|c|}
\hline & \multicolumn{9}{|c|}{ Education } \\
\hline & $\begin{array}{c}\text { No } \\
\text { Degree }\end{array}$ & $\begin{array}{l}\text { All w/ } \\
\text { Degree }\end{array}$ & $\begin{array}{c}\text { Adv. } \\
\text { Degree }\end{array}$ & Eng. & $\begin{array}{l}\text { Non- } \\
\text { Eng. }\end{array}$ & $\begin{array}{c}\text { BS } \\
\text { Degree } \\
\end{array}$ & $\begin{array}{c}\mathrm{BA} \\
\text { Degree } \\
\end{array}$ & Bus. & $\begin{array}{l}\text { Non- } \\
\text { Bus. }\end{array}$ \\
\hline Mean & 1.35 & 1.74 & 1.20 & 1.71 & 1.56 & 1.75 & 1.25 & 1.36 & 1.73 \\
\hline $\mathrm{N}$ & 23 & 89 & 10 & 66 & 34 & 80 & 8 & 14 & 98 \\
\hline
\end{tabular}


Statement J: Public Interest

"Generally speaking, the public is very interested in and aware of the policies and activities of BPA." This statement is intended to determine to what extent BPA executives feel that the public is knowledgable of BPA's function. Perceptions of public awareness are important because they may reflect perceived public support or lack of it. Further, perceptions may indicate the extent to which BPA feels freedom from or concern with public scrutiny. It is possible that an agency that notes public apathy or ignorance toward its activities may feel less inclined to worry about the public interest. . On the other hand, perceptions of public disinterest may promote greater feelings of a public trust with employees. Table XXVI lists the results. 
TABLE XXVI

PUBLIC INTEREST

"Generally speaking, the public is very interested in and aware of the policies of BPA."

$\begin{array}{ccccc}1 & 2 & 3 & 4 & 5 \\ \begin{array}{c}\text { strongly } \\ \text { agree }\end{array} & \begin{array}{l}\text { mildly } \\ \text { agree }\end{array} & \text { neutral } & \begin{array}{c}\text { mildly } \\ \text { disagree }\end{array} & \begin{array}{c}\text { strongly } \\ \text { disagree }\end{array}\end{array}$

\begin{tabular}{|c|c|c|c|c|c|c|c|c|c|c|c|}
\hline & \multirow[b]{2}{*}{ Total } & \multicolumn{5}{|c|}{ GS Level } & \multicolumn{5}{|c|}{ Age } \\
\hline & & 11 & 12 & 13 & 14 & 15 & $\overline{20 s}$ & $30 \mathrm{~s}$ & $40 \mathrm{~s}$ & $50 \mathrm{~s}$ & $60 s$ \\
\hline Mean & 3.68 & 3.75 & 3.73 & 3.41 & 3.89 & 3.86 & 3.71 & 4.00 & 3.71 & 3.52 & 3.75 \\
\hline $\mathrm{N}$ & 112 & 32 & 37 & 27 & 9 & 7 & 7 & 31 & 28 & 29 & 12 \\
\hline
\end{tabular}

\begin{tabular}{|c|c|c|c|c|c|c|c|c|c|}
\hline & \multicolumn{9}{|c|}{ Education } \\
\hline & $\begin{array}{c}\text { No } \\
\text { Degree } \\
\end{array}$ & $\begin{array}{l}\text { All w/ } \\
\text { Degree }\end{array}$ & $\begin{array}{c}\text { Adv. } \\
\text { Degree }\end{array}$ & Eng. & $\begin{array}{l}\text { Non- } \\
\text { Eng. }\end{array}$ & $\begin{array}{c}\text { BS } \\
\text { Degree } \\
\end{array}$ & $\begin{array}{c}\text { BA } \\
\text { Degree } \\
\end{array}$ & Bus. & $\begin{array}{l}\text { Non- } \\
\text { Bus. }\end{array}$ \\
\hline Mean & 3.78 & 3.65 & 3.40 & 3.52 & 3.94 & 3.60 & 4.00 & 3.93 & 3.63 \\
\hline $\mathrm{N}$ & 23 & 89 & 10 & 66 & 34 & 80 & 8 & 14 & 98 \\
\hline
\end{tabular}

Statement K: Responsiveness

"In general, BPA is very responsive to the wishes of the groups that it serves." This statement was intended to determine how executives rated BPA in responsiveness to their clientele. The clientele identified by BPA executives in Table $\mathrm{X}$ (What group or groups benefit most from BPA policies?) included the general public, public and private utilities, industry, and federal agencies. Is BPA 
responsive to the wishes of this clientele; and if so, to what extent? Table XXVII scales the opinions on the statement.

TABLE XXVII

\section{RESPONSIVENESS}

"In general, BPA is very responsive to the wishes of the groups that it serves."

$\begin{array}{ccccc}1 & 2 & 3 & 4 & 5 \\ \begin{array}{c}\text { strongly } \\ \text { agree }\end{array} & \begin{array}{l}\text { mildly } \\ \text { agree }\end{array} & \text { neutral } & \text { mildly } & \text { strongly } \\ & & & \text { disagree } & \text { disagree }\end{array}$

\begin{tabular}{|c|c|c|c|c|c|c|c|c|c|c|c|}
\hline & \multirow[b]{2}{*}{ Total } & \multicolumn{5}{|c|}{ GS Level } & \multicolumn{5}{|c|}{ Age } \\
\hline & & 11 & 12 & 13 & 14 & 15 & $20 \mathrm{~s}$ & $30 \mathrm{~s}$ & $40 \mathrm{~s}$ & $50 \mathrm{~s}$ & $60 \mathrm{~s}$ \\
\hline Mean & 1.65 & 1.73 & 1.84 & 1.44 & 1.56 & 1.29 & 2.14 & 1.74 & 1.61 & 1.69 & 1.33 \\
\hline $\mathrm{N}$ & 113 & 33 & 37 & 27 & 9 & 7 & 7 & 31 & 28 & 29 & 12 \\
\hline
\end{tabular}

\begin{tabular}{|c|c|c|c|c|c|c|c|c|c|}
\hline & & & \multicolumn{4}{|c|}{ Education } & \multicolumn{3}{|c|}{$\therefore$} \\
\hline & $\begin{array}{c}\text { No } \\
\text { Degree } \\
\end{array}$ & $\begin{array}{l}\text { All w/ } \\
\text { Degree }\end{array}$ & $\begin{array}{c}\text { Adv. } \\
\text { Degree }\end{array}$ & Eng. & $\begin{array}{l}\text { Non- } \\
\text { Eng. }\end{array}$ & $\begin{array}{c}\text { BS } \\
\text { Degree } \\
\end{array}$ & $\begin{array}{c}B A \\
\text { Degree } \\
\end{array}$ & Bus. & $\begin{array}{l}\text { Non- } \\
\text { Bus. }\end{array}$ \\
\hline Mean & 1.50 & 1.70 & 1.30 & 1.60 & 1.65 & 1.76 & 1.50 & 1.64 & 1.66 \\
\hline $\mathbb{N}$ & 24 & 89 & 10 & 67 & 34 & 80 & 8 & 14 & 99 \\
\hline
\end{tabular}




\section{ATTITUDINAL SUMMARY}

The purpose of the attitudinal section was to quantify possible differences in attitudes as they relate to variables of background, education, and training. But differences and similarities between and within particular variables may not mean much until they are compared in their degree of difference. To accomplish this, it is necessary to compute the degree of differences attained. The computation was done by grouping each variable (GS level, age, and education) for each statement and calculate Delta, or the greatest change represented by subtracting the smallest average from the largest for each grouping. For example, on Table XXVII the lowest average for GS level was 1.29 (GS 15) while the highest was 1.84 (GS 12). Delta, then, is the subtrahend of 1.84 minus 1.29 , or .55 . If there were only a few hundredths difference for a variable for all the respondents, then we may say that that variable is not particularly "active" for that statement. On the other hand, if larger differences appear within one variable group, then possibly that variable does in fact have an influence on attitudes. Table XXVIII calculates Delta for all the statements.

Presumably, the larger Delta becomes, the greater is the importance of that variable in identifying differences in attitudes on that particular statement. For example, statement A on Table XXVIII shows that Delta for GS level is 
TABIE XXVIII

DIFFERENCE BETWEEN IARGEST AND SMALLEST MEAN (DELTA) FOR EACH VARIABLE AND STATEMENT

\begin{tabular}{|c|c|c|c|c|c|c|c|c|c|c|c|}
\hline & \multicolumn{11}{|c|}{ Statement } \\
\hline & $A$ & $\mathrm{~B}$ & $\mathrm{C}$ & D & $E$ & $F$ & $\mathrm{G}$ & $\mathrm{H}$ & $I$ & $\mathrm{~J}$ & $\mathrm{~K}$ \\
\hline GS Leve 1 & $1.20 *$ & $.86 *$ & $.72 *$ & $.66 *$ & $.42 *$ & $.50 *$ & $1.00 *$ & $1.70 *$ & $.60 *$ & $.48 *$ & $.55 *$ \\
\hline Age & $1.68 *$ & $.91 *$ & $1.16 *$ & $.94 *$ & $.28 *$ & $.67 *$ & $.90 *$ & .37 & $.64 *$ & $.48 *$ & $.81 *$ \\
\hline No degree vs. degree & .07 & .29 & .41 & .21 & .03 & .13 & $.68 *$ & .25 & .39 & .13 & .20 \\
\hline No degree vs. adv. degree & .48 & .17 & .37 & .14 & $.32 *$ & .21 & .48 & .66 & .15 & $.38 *$ & .20 \\
\hline Engineer vs. non-engineer & .10 & .45 & .27 & .06 & .03 & .24 & .31 & .18 & .15 & $.42 *$ & .05 \\
\hline BS vs. BA degree & .13 & .41 & .59 & .19 & $.23 *$ & $.47 *$ & .19 & $.70 *$ & $.50 *$ & .40 & .26 \\
\hline Business vs. non-business & $1.04 *$ & .25 & $.69 *$ & $.49 *$ & $.31 *$ & $.45 *$ & .02 & $.72 *$ & .37 & .30 & .02 \\
\hline Mean Delta & .67 & .48 & .60 & .38 & .23 & .38 & .51 & .67 & .40 & .37 & .30 \\
\hline
\end{tabular}

*Delta equal to or greater than mean delta for all variables in statement (computed vertically).

Key to statements:
A - Environmentalists' Concerns
B - Aluminum Plants
C - Necessity of Growth
D - Reduce Economic Expansion
E - Conservation of Energy
F - Power Shortages 
1.20, indicating that there is a significant difference in attitudes on that particular statement for GS classification. On the other hand, Delta for "Degree versus no degree" is only .07 for Statement $A$, indicating that possession of a college degree by itself is not a good predictor of attitudinal differences. Delta is considered to be significant if it is equal to or greater than the average Delta for each statement (average Delta is shown on the bottom line of Table XXVIII and is computed by averaging Delta vertically). Delta meeting this criteria are starred $(*)$. Reading across Table XXVIII, we see that in eleven of eleven cases Delta is greater than mean Delta for GS level. Delta is significant for age in ten of eleven cases; however, the education variables (with the possible exception of business/non-business) are not by themselves good predictors of attitudinal differences for the statements presented. In other words, education variables tested appear to have little significant influence on differences in these particular attitudes. 


\section{CHAPTER VI}

\section{DISCUSSION}

The preceding chapter should be analyzed on two levels. First, an effort must be made to explain why age and Gs level proved to be reasonably predictive indicators of differences in attitudes. Also, lack of differences in attitudes for educational variables must be explained. Second, looking beyond internal variables, the attitudes expressed by BPA executives as a whole must be analyzed. That is, despite differences in attitudes among some subgroups, definite trends in direction of attitudes can be seen for the aggregate. Why, for example, do the great majority of $\mathrm{BPA}$ executives see environmentalists as "too concerned with their narrow goals?" (Table XV)

Differences in attitudes for age and GS level are probably related because GS level tends to increase with age (Table 1). Older executives may feel a stronger attachment to the status guo than do younger and lower level executives. This may partly explain the generally increasing conservativeness of many responses with increase in age and GS level. Organizational loyalties and concern with retirement and promotion may increase with age and position. Yet some attitudes expressed by executives in their twenties 
were more oriented toward organizational tradition than were some attitudes expressed by those in their thirties. Statements B, C, G and F are examples of this. Perhaps this is because those in their twenties may be more susceptible to organizational and peer group pressures in their desire to conform to reduce anxiety and secure their job positions. Those in their thirties were most apt to express dissident attitudes. This group may feel more secure and thus more free to express deviant viewpoints.

Differences in attitudes for GS level may be partly a function of access to or interest in agency information and policies. Presumably, those in higher positions are "in the know" on more issues than those at lower positions. Aiso, the higher an executive ascends the bureaucratic ladder, the wider his horizons tend to be. He should not limit his knowledge and interests to his own narrow tasks; he should look beyond more toward the "big picture" as it is presented to him. Those who seek promotion are often more successful at it through careful conformity to bureaucratic objectives rather than deviance from them. Indeed, Table XIII and XIV indicate that perceptions of influence tend to increase with increase in age and GS level. What this suggests is that conformity to the organizational viewpoint may lead to greater social acceptance and confidence. Advancement in grade level may very well highly depend on acceptance and confidence, and hence on conformity. 
The author confesses to be rather surprised at the dearth of differences in attitudes for educational variables. Several explanations for this can be offered. First, amount of education or curriculum has little effect on attitudes. Second, organizational norms and peer group influences outweigh or counteract educational influences. Third, the wrong educational variables and attitudes may have been analyzed. Fourth, a combination of these explanations is responsible. The fourth explanation is probably the most fertile to explore.

Attempting to find differences in attitudes at BPA between those with four year degrees and those without degrees may be somewhat futile because of the wide exposure of BPA executives to at least "some college." Ninety-three per cent of the sample had attended "some college" while $79 \%$ have one or more degrees. Thus, the average executive has only slightly less than a college degree (Table II). If a college education has an influence on attitudes, then surely differences between those with degrees and those without degrees would be somewhat muted if the only distinction between them is longevity in school and a diploma in hand.

Expected differences between engineers and nonengineers did not materialize either. This may be partially due to the selection of the data to be used. "Engineers" were considered to be anyone who had studied predominately engineering courses at college, regardless of whether or not 
the individual had earned a degree. Non-engineers consisted of everyone else. Unfortunately, no good comparisons could be made with other disciplines because of the small numbers involved. Thus, the non-engineers were a mixture of economists, social scientists, mathematicians, and anyone left over. This resulted in a somewhat adulterated sample. Part of the difficulty in this study is the lack of personnel with contrasting background variables with which to make comparisons. The typical BPA executive is male, well educated, with a background in engineering. Other disciplines and those with only a high school education are almost non-existent. The striking thing about the BPA executives is not differences, but similarities. The same holds true for the attitudinal data: the data is not notable for differences in organizational attitudes, but for its similarities. Only for statements $G$ and $H$ was the total average attitude near 3.0 or neutral. A mean close to 3.0 is indicative of two possibilities: one, the great majority of respondents were neutral on the issue, or, two, there was a great diversity of opinion which averaged out at neutral because of the extremes. Statements $G$ and $H$ are examples of the latter occurrence.

The remaining statements elicited rather strong average sentiment one way or the other, as shown in Table XXIX. The question, then, turns from asking what causes differences in attitudes to asking what causes similarities. What forces 
TABLE XXIX

A COMPARISON OF MEANS FOR

ALI STATEMENTS

\begin{tabular}{ll}
\hline \multicolumn{1}{c}{ Statement } & Mean \\
\hline A - Environmentalists' Concerns & 2.27 \\
B - Aluminum Plants & 3.90 \\
C - Necessity of Growth & 2.46 \\
D - Reduce Economic Expansion & 3.87 \\
E - Conservation of Energy & 2.20 \\
F - Power Shortages & 1.39 \\
G - Policy Disagreement & 2.95 \\
H - Power Contracts & 2.94 \\
I - Compatibility of Functions & 1.66 \\
J - Public Interest & 3.68 \\
K - Responsiveness & 1.65 \\
\end{tabular}

contribute to the general concurrence on many issues at BPA?

$B P A$ 's main function is to market and transmit power. Marketing is the complex but relatively minor function of selling, accounting, and contracting for power deliveries. The major function--that of transmitting power to the buyers--is a highly technical one, requiring the expertise of engineers and specialists to complete. Sixty-seven per cent of the executives at BPA have had at least some engineering schooling. Another $9 \%$ have had formal education at the college level in mathematics and the physical sciences (Table III). It is thus not an overgeneralization to consider BPA as an engineering institution, organized by necessity to master the complex world of high voltage transmission, con- 
verters, relays, transformers, and tower design. All other functions are secondary to and dependent on the engineer and his ability to solve the technical problems in transmission of energy. No power can be sold if it cannot be delivered. Engineers are the backbone of. BPA and provide the majority of the personnel pool from; which to select those who will advance into other areas within the organization. Engineers whose abilities transcend the technical may be promoted into such areas as personnel or administration. This is not to say that an individual must be an engineer to advance at BPA. However, even in an administrative capacity, the ability to communicate with technical jargon and to understand the principles involved in power transmission proves invaluable. Because BPA is a technical institution, its manpower pool is heavily oriented toward the engineering sciences; BPA must draw from this source for the majority of its future leadership.

Because these individuals tend to share certain similarities and because these individuals will help to make and carry out policy, we must look deeper into the background and values associated with engineers as they apply to the norms at BPA. This is not to suggest that norms at BPA are all identical or that some sort of conspiracy of propaganda exists at the agency to instill uniform attitudes. Rather, as Kaufman notes: 
. . the norms evolve without conscious or systematic effort on anyone's part; indeed, it sometimes appears the individuals controlled by them could not articulate them if they were asked to, although the observer can see quite plainly that the standards determine what personnel do and decide. 21

Can these norms be identified? How do they affect policy? How are norms created and reinforced? What is the relation between engineering background variables, norms, and policy? It is to these questions--as they apply to BPA--that we now turn.

As a preliminary to this discussion; the term "value" must be given a working definition. Milton Rokeach defines a value as ". . an enduring belief system that a specific mode of conduct or end-state of existence is personally and socially preferable to various alternative modes of conduct or end states of existence." 22 A less unwieldy adaption might term a value as a lasting preference for a particular state of affairs. Recent research has found that values do change, but the permanence of that change is questionable. Seth Arsenian, in conducting a 25 year follow-up on student values, concludes that values do often change during the college years, generally in the direction of the college's special orientation. He also found that values often changed or reverted to pre-college levels after the passage of time.

${ }^{21}$ Kaufman, op. cit., p. 73 .

22 Milton Rokeach, Beliefs, Attitudes, and Values: A Theory of Organization and Change, (San Francisco: JosseyBass, 1968), p. 160 . 
In other cases, values held rather stable. ${ }^{23}$

Generally, then, there is little evidence that college training permanently changes values in any predictable manner. Peer group influence is probäbly a much stronger force on values during college than is the curriculum or professors. However, other evidence suggests that there are definite differences in values between academic majors. By a self-selection process, students are drawn to the area where they are best suited intellectually and socially. 24 Here, pre-existing values tend to be reinforced, and differences in values with other academic fields tend to be sharpened. 25 . Further evidence of differences among students in academic areas is found for intelligence and liberalism of attitudes. The most intelligent students tended to gravitate toward the physical sciences, engineering, and mathematics. The middle level of intelligence was often found in literature and the social sciences. The bottom level was most often represented in agriculture, business, home economics, and education.' But social science students were

\section{${ }^{23}$ Seth Arsenian, "Change in Evaluative Attitudes} During Twenty Five Years," Journal of Applied Psychology, LIV, (Aug. 197.0), pp. 302-304.

${ }^{24}$ Carl Bereiter and Mervin B. Freedman, "Fields of Study and the People in Them," in Nevitt Sanford, ed., American College, (New York: Wiley, 1962), p. 569.

${ }^{25} \mathrm{C}$. William Huntley, "Changes in Study of value Scores During the Four Years of College," Genetic Psychology Monographs, LXXI, (May 196.5), pp. 349-383. 
found to be the most liberal in attitudinal studies, while students in agriculture and engineering were among the least liberal. Students of literature, arts, and natural sciences were between the extremes. 26

Value rankings of engineers with nine other curricular groups placed engineers second in economic values, third in religious values, fourth in social and political, sixth in theoretical, and eighth in esthetic values. 27 It may be surmised from these findings that engineering students are not particularly comfortable with the theoretical and the esthetic. They are most comfortable with mathematics and science where the laws and formulas are given or applied to predictable events with predictable results. The hypothetical and the theoretical in the social sciences are often not concrete enough for engineers. They also have a low esteem for political science and sociology as useful tools. These two social sciences were ranked fortieth and forty-first respectively (from a list of 44 possible choices) by career engineers who were asked to recommend courses for future engineering students. 28 The engineering students are not unique in their self-selection of areas of study for which

\footnotetext{
${ }^{26}$ Bereiter and Freedman, 1oc. cit., pp. 564-68. 27 Huntley, 1oc. cit., p. 373.

${ }^{28}$ William K. Lebold, Robert Perrucci, and Warren Howland, "The Engineer in Industry and Government," Journal of Engineering Education, LVI, (March 1966), p. 249 Table 5.
} 
they are best equipped and comfortable. The social science student may be poor at mathematics and science and better adapted to the inexactitudes of the study of people.

The engineer is essentially a scientist. He is required to have only a smattering of social science, literature, history, and English in his curriculum. After his formal training, the engineer, like all students, is faced with career selection. "The person making a vocational choice in a sense 'searches' for situations which satisfy his hierarchy of adjustive orientations." 29 Again, we see the self-selection process at work where the individual seeks to reflect his personality in his career choice. A pattern is developed where individuals with value systems already established attend a college and tend to select a major with which they are skilled and familiar. This choice will likely co-exist nicely with his pre-existing value structure. Here, slanting in the direction of his college's special orientation, he tends to reinforce his values and sharpen the distinction between his values and other academic areas. After graduation he continues to seek familiar surroundings in a career that will not upset his orientation. It may be said that "birds of a feather do flock together." Herbert Kaufman alludes to this phenomenon in The Forest Ranger:

$29 \mathrm{~J}$. L. Holland, "A Theory of Vocational Choice," Journal of Counseling Psychology, VI, (1959), p. 35. 


\begin{abstract}
- . the men choosing professional forestry as an occupation may be said to have demonstrated by that choice a set of interests and attitudes indicative of a degree of receptivity to the requirements of life in the Forest Service. . . . Willingness to conform is in this sense employed as an initial criterion of selection, a standard applied to themselves by the young men crossing the threshold to professional training. . . 30
\end{abstract}

If an engineer finds that he does not fit in an organization (or if his peers decide it for him), he may leave, thus further consolidating the like-mindedness of those who remain. It is important at this point to emphasize that the generalizations expressed here do not apply solely to engineers. Any organization that draws predominately from one group risks this self-narrowing of perspectives. An agency that selects its personnel primarily from among social workers or lawyers should expect similar perspectives as a result of that selection.

The data from the attitudinal comparisons suggests that not only does the engineering viewpoint dominate (perhaps from sheer numbers), but that non-engineers to a great extent have accepted these pervasive attitudes. The attitudes at BPA are strikingly similar largely because the agency selects its personnel from a relatively homogeneous and narrow group. Yet personnel at BPA from outside of this narrow group seem to have been socialized toward similar attitudes. This suggests that personnel selection and ${ }^{30}$ Kaufman, op. cit., p. 165. 
socialization are complementary tools with which organizations can instill fairly uniform and compatible attitudes. This relationship between socialization and selectivity has been noted before:

All other things being equal, socialization and selectivity can frequently substitute for each other, on the simple ground that . . . the organization can recruit participants who have the characteristics through training and education. On the other hand, if the organization has to accept every member who wishes to join, or every member of a specific but larger and unselected group, it has to turn to socialization to produce the desired result. ${ }^{31}$

At this juncture in the study it is wise to reconsider the purpose of the research. The original intent was to attempt to find a link between background, training, and education with attitudes and hence policy. The link between background variables was to have been differences in attitudes; however, many of these expected differences did not materialize. As a result, the emphasis has had to shift to possible causes of similarities in attitudes instead of differences. BPA was labeled an engineering institution and the impact of college and the self-selection process of the engineer was discussed. Now the question turns toward asking whether or not the engineering perspective at BPA has an impact on policy.

31 Amitai Etzioni, A Comparative Analysis of Complex Organizations, (New York: The Free Press, 1961), p. 158. 
CHAPTER VII

\section{SUMMARY AND CONCLUSIONS}

\section{GENERAL SUMMARY}

One does not need to be an artist to judge rather quickly that a typical BPA transmission tower is an ugly addition to the landscape. Yet, to an engineer, that tower represents the genius of his profession. A tower is designed for maximum efficiency, using a minimum of steel to support a huge weight in power cable against wind and other elements. This engineer does not take kindly to an environmentalist who considers the tower to be a rape of the countryside. To an engineer, energy enables man to perform work which would otherwise have to be done by hand or not done at all. His tower efficiently transmits energy and that is all it is intended to do. Work requires energy, and BPA's job is to transmit energy. When an environmentalist suggests that energy use be curtailed, the engineer sees that as advocating less performance of work.

It is thus not difficult to understand the animosity that exists between $\mathrm{BPA}$ and the environmentalist. The two groups speak a different language and operate on contrasting value systems. BPA is quick to point out all that it has done in the spirit of environmental protection--sub station 
beautification, narrower right-of-ways, impact statements, etc.--but the majority of these projects and procedures were forced on the agency after the surge of environmental concerns by groups on the outside of BPA who had a different perspective. Suspicion of the environmentalists by the majority of BPA executives suggests that further meaningful environmental policy changes will only come as a result of pressures from outside of BPA rather than internal motivation. Already the required environmental impact statements are considered to be another political hurdle that must be completed before the much needed work at hand can continue. Because work must be performed and energy potential is not to be wasted, BPA will continue to perceive energy supply and transmission as the dominant priority and to consider environmental concerns as secondary to those considerations. The engineer tends to have a low estimate of politics and politicians. Yet BPA is dependent on the political process for its lifeblood--its Congressional appropriations. Budgetary concerns take up much of the time of many BPA executives and a growing number would prefer that BPA be an independent agency with authority to disperse its revenue as it sees fit and to plan and construct new generating facilities. But this prospect is viewed with some pessimism because the politician is not seen as having the wisdom to see the obvious. However, BPA will likely push for independence in the future, possibly timed to coincide with a power 
shortage to add an emergency emphasis to the request. A move toward independent status similar to that of TVA would not only be consistent with BPA's goals, but would further reflect the special desire of the engineer to be well insulated from the whims of politics and politicians. If independence were to be granted, BPA would be free to meet energy demand as befits its perception of work and economic potential. Barring independence, the Hydro-Thermal Program has strong support among BPA executives as a stop-gap measure which also increases regional dependence on BPA as energy coordinator.

The engineer tends to see continued growth of business and industry as natural extensions of the "work requires energy" ethic. If energy potential is available, it should be used. If energy is demanded, that demand should be supplied. Growth is seen as a function of consumer demand; to deny demand is to upset the ordered relationship between work and energy. Growth, therefore, is to be expected and certainly should not be limited artificially. While the engineer covets efficiency, he cannot tolerate waste. Waste of energy is as abhorent to him as is limiting demand. The engineer thus favors efforts to avoid waste of energy resources. But favoring conservation of energy may be an element of his efficiency ethic rather than an environmental concern. Future BPA efforts at "conservation" are likely to include increasing generation capacity to meet demand while 
attempting to limit waste.

The engineering perspective has its roots in the efficiency ethic and the work-energy relationship, combined with a belief in the natural function of supply and demand. Efficiency requires maximum benefit with minimum expenditure of resources. Esthetic considerations must be secondary to efficiency. Work requires energy and to limit energy is to limit work performed by society. Therefore, if energy (work) is demanded, it must be supplied, and those who would interfere with this natural function are seen as Utopians. Conservation of energy is seen as an acceptable notion provided it does not hamper supplying "legitimate" demand. Growth of business and population is perceived as another natural outgrowth of demand. The politician is judged to be hopelessly tied to special interests, and thus unable to represent the true needs of the public. The engineer knows what society needs--efficient energy supply so that work can be performed.

Manifestations of this engineer mentality are seen in BPA policy. The Hydro-Thermal Program is an extension of the perceived need to supply all demand. The attitude toward the environmentalist is a function of the engineer's disdain for Utopianism. Encouraging economic growth is a ramification of the notion that work and energy are not to be artificially limited. Esthetic considerations are seen as acceptable, but secondary to the' energy requirements of society. And, 
the preference for independence for BPA from politicial control is partly an expression of the engineer's lack of trust toward the politician.

Policy, it is to be recalled, is not only what an agency says it does, but what it actually does or does not do. Policy at BPA is, then, subtly but surely shaped and directed in the mold of the engineer. The engineering perspective becomes the standard with which all policy is judged as it is formulated and executed. Because no one at BPA is elected, the policy which is made there has little accountability to the public. Yet, the policies pursued at BPA affect everyone in the Northwest. The task for government and administrators is to find methods to formulate and execute policy in directions that are planned and accountable, while preventing or controlling policy that is made by the perspective of the few.

\section{CONCLUSIONS}

(1) An attempt has been made to link background, education, and training to policy at BPA. Some significant differences in attitudes were detected for certain variables but not for others. The most significant findings were not differences in attitudes, but similarities. Evidence was offered which suggests that the effect of formal education is not so much one of molding certain attitudes and values, but one of reinforcing pre-existing values through a self- 
selection process. The student seeks comfort and conformity in familiar academic surroundings. The career selection process can be seen as an extension of this phenomenon.

(2) Most organizations are dominated by some group with similar backgrounds. Bonneville Power Administration executives are dominated by well educated Northwest natives who studied engineering at a Northwest state college or university. It is suggested that these similarities of education and training have been largely self-selected, but produce a perspective that is more alike than different.

(3) Policy is affected by this similarity of perspective. It is seen in attitudes toward growth, environmentalists, conservation, and efficiency. Attitudes can be seen in policy not only in terms of programs (or the lack of them) but also in the interest or disinterest with which policy is carried out. Others in a bureaucracy with views that differ from the preponderant perspective may seek to conform to them to reduce anxiety and to facilitate advancement.

(4) Background variables are only a few of many factors that affect policy. Others include hierarchical dictates, bureaucratic support seeking, and the bureaucratic survival instinct. But other policy factors are influenced by the perspective with which other directives, dictates, 
pressures, and ideas are magnified, diminished, or distorted to conform to a certain organizational paradigm. 


\section{BIBLIOGRAPHY}

Arsenian, Seth. "Change in Evaluative Attitudes During Twenty Five Years." Journal of Applied Psychology. LIV (August, 1970), 302-304.

Blau, Peter M. The Dynamics of Bureaucracy: A Study of Interpersoñl Relations in Two Government Agencies. Revised edition. Chicago: Univ. of Chicago Press, 1963.

Bonneville Project Act. 16 U.S.C. 832, Chapter 12B.

Bonneville Regional Advisory Council. Conference Proceedings. Portland, Oregon, 1972 .

Di Palma, Giusseppi, and McClosky, Herbert. "Personality and Conformity: The Learning of Political Attitudes." American Political Science Review. LXIV (December, 1970), 1054-73.

Dreitzel, Hans Peter. "Social Science and the Problem of Rationality: Notes on the Sociology of the Technocrats." Politics and Society. II (Winter, 1972); 165-82.

Dye, Thomas R. Understanding Public Policy. Englewood Cliffs, N. J.: Prentice-Hall, 1972.

Etzioni, Amitai. A Comparative Analysis of Complex Organizations. New York: The Free Press, 1971.

Holland, J. I. "A Theory of Vocational Choice." Journal of Counseling Psychology. VI (1959), 35-44.

Huntley, C. William. "Changes in study of Value Scores During the Four Years of College." Genetic Psychology Monographs. LXXI (May, 1965), 349-83.

Janowitz, Morris: The Professional Soldier: A Social and Political Portrait. New York: The Free Press, 1971.

Kaufman, Herbert. The Forest Ranger: A Study of Administrative Behavior. Baltimore: The Johns Hopkins Press, 1967. 
Lebold, William K; Perrucci, Robert; and Howland, Warren. "The Engineer in Industry and Government." Journal of Engineering Education. LVI (March, 1966), 237-74.

McKinley, Charles. Uncle Sam in the Northwest: Federal Management of Natural Resources in the Columbia River Valley. Berkeley: Univ. of California Press, 1952.

Mulford, Charles L. et al. "Selectivity, Socialization, and

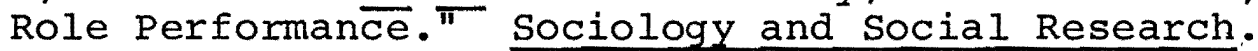
LIII (October, 1968), 68-77.

Navasky, Victor S. Kennedy Justice. New York: Athenium, 1971 .

Ogden, Daniel M. "The Development of Federal Power Policy in the Pacific Northwest." Ph.D. dissertation, Univ. of Chicago, 1949, Volume 1. (Photostated.)

Rokeach, Milton. Beliefs, Attitudes, and Values: A Theory of Organization and Change. San Francisco: JoseyBass, 1968 .

U.S., Department of the Interior, Bonneville Power Administration. About BPA. Information office. July, 1972.

U.S., Department of the Interior, Bonneville Power Administration. Annual Report. 1969, 1970, 1971, and 1972.

U.S., Department of the Interior, Bonneville Power Administration. A Ten Year Hydro-Thermal Program for the Pacific Northwest. July,. 1969.

Warner, W. Lloyd, et al. The American Federal Executive. New Haven: Yale Univ. Press, 1963.

Wilkinson, Rupert. Gentlemanly Power: British Leadership and the Public School Tradition. London: Oxford Univ. Press, 1964 . 


\section{APPENDIX A}

\section{METHODOLOGY}

The primary means (in addition to a limited number of personal interviews) of determining certain characteristics and attitudes of BPA executives was through a written questionnaire. $^{32}$ A pre-test was conducted on ten men and the survey was modified somewhat after judging their responses and criticisms. In mid-July of 1972, the final questionnaire (see Appendix B) was sent to 140 randomly selected BPA employees in the grades of General Services (GS) 11 through 15. By chance, the sample did not include any executives over GS 15 due to the low population (5) of GS $16 \mathrm{~s}$ and 17s. Names were selected from a list of employees supplied by BPA through the use of a table of random numbers.

For the purposes of this study, the respondents were termed "executives" although it is acknowledged that some of the respondents would be more accurately labeled "middle management" or technical specialists. Selection of individuals between GS 11 through 15 was based on a belief that personnel at all levels can make or affect policy, and that

${ }^{32}$ The author wishes to extend credit to W. Lloyd Warner, et al., The American Federal Executive, (New Haven, Yale Univ. Press, 1963), Appendix A, pp. 267-268 for ideas and format incorporated into the questionnaire. 
middle level personnel will provide the main pool from which future leadership will be drawn. The total sample of 140 represented $14 \%$ of the employees in grades GS 11 through 17 . Included with the questionnaire were two cover letters. One was from the author which explained the nature and purpose of the study. The other cover letter (on BPA stationery) was from the Chief of Personnel at BPA who authorized the study and asked for fill cooperation from employees. An IBM card was adapted for use as a reminder card and sent to those who had not returned the questionnaire within two weeks. A code number on each questionnaire enabled the author to determine who had not responded. After the final cut-off date for returns, the code sheet was destroyed and each respondent "became a number." The questionnaire guaranteed confidentiality and the procedure insured anonymity. All questionnaires and reminders were sent through the BPA distribution system in government envelopes. Completed questionnaires were returned by U.S. mail in a stamped, addressed envelope to the Political Science Department at Portland State University. Data were then coded and punched onto IBM cards for sorting and counting. One hundred fourteen usable questionnaires were returned, a rate of 81.48 as shown on Table Xxx.

Despite the overall success of the questionnaire, some information proved to be of little use, some too unwieldy to analyze, and some questions received poor responses. 
TABLE XXX

SAMPLE AND RETURNS

\begin{tabular}{lrrrrrrrrr}
\hline & Total & GS 11 & GS 12 & GS 13 & GS 14 & GS 15 & GS 16 & GS 17 \\
\hline $\begin{array}{l}\text { Actual } \\
\text { population }\end{array}$ & 982 & 272 & 368 & 210 & 88 & 39 & 3 & 2 \\
$\begin{array}{l}\text { Sample } \\
\begin{array}{l}\text { Number of } \\
\text { returns }\end{array}\end{array}$ & 140 & 38 & 53 & 31 & 11 & 7 & 0 & 0 \\
$\begin{array}{l}\text { Per cent } \\
\text { returned }\end{array}$ & 81.4 & 33 & 37 & 28 & 9 & 7 & - & - \\
\hline
\end{tabular}

Question $16 \mathrm{a}$ is a case in point. Respondents were asked to list a "program" to prevent a power crisis. It was hoped that comparisons of emphasis could be made and correlated with background variables. However, the responses were dismal because the question was too vague and required too much time to thoughtfully complete. Question $16 \mathrm{~b}$ was asked with the expectation that personnel would have various notions of what the mission of BPA actually is. However, most executives answered "market power," "transmit power," or "market and transmit power." Not enough variety existed to make significant correlations. Question 16c failed largely from lack of response. In summary, the questionnaire proved to be too long and time consuming for the respondents; however, good responses were received on questions that could be scaled or answered with a short response. 


\title{
APPENDIX B
}

\section{SURVEY QUESTIONNAIRE}

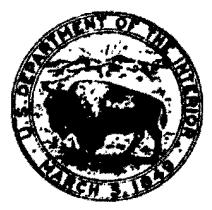

In reply sefer to:

\section{United States Department of the Interior}

BONNEVILLE POWER ADMINISTRATION

P.O. Box 3621, POKTI.AND, OREOON 9? 208

\section{Womorandun}

To:

\author{
From: Victor H. English, Ohtef \\ Branch of Rersonnel Management \\ Subject: Cooperative Project with Portland State \\ University and Patlip G. Millam
}

BPA is cooperating with the School of Social Sclence, Portland State Oniveraity, in a project conducted by Mr. Philip G. Milian. He is attempting to determine the relationehip, if any, of individual beckgrounds to policy developent in a bureaucratic structure.

Our part of the work is to ask your cooperation in completing the encloaed questionnalre and turning it to him. Complete instruclons accompany the questionnaire.

Your help in this project will be appreciated.<smiles>[Y]#[W]</smiles>

Enclosures 


\author{
BPA EXECUTIVE STUDY \\ DEPARTMENT OF POLITICAL SCIENCE \\ PORTLAND STATE UNIVERSITY
}

Dear respondent:

Your name has been selected on a random basis from a list of BPA executives. We are asking that you cooperate on a study that will take approximately 17 minutes of your time.

The attached questionnaire has been prepared by Philip G. Millam, a graduate student of political science at Portland State University. The questionnaire is one of the means that I am employing to gather data about personnel at Bonneville Power Administration. The information will be used as part of a Master of Arts thesis.

Specifically, I am interested in the following questions as they pertain to Public Administration: (1) Where and how have certain levels of BPA personnel received their education, training, and background? and. (2) Do different backgrounds reflect different attitudes toward certain functions of BPA?

The information sought in this questionnaire will be held in the strictest confidence. Due to the nature of the survey, I could conceivably determine which individuals answered which questions. However, this is neither my purpose nor my intent. No BPA management personnel will have access to the individual data. In no way will individuals be compared on a basis of performance or qualifications, nor will comparisons be made with other agencies, public or private.

This questionnaire gives you the opportunity to express your opinions and creative solutions to some difficult problems faced by $B P A$ and the Northwest. With your cooperation, this research project could add important knowledge to the limited information available on the relation between background and administrative practices.

I sincerely hope that you will take the time from your busy schedule to thoughtfully respond to this questionnaire. Please fold the completed questionnaire and mail it in the stamped, addressed envelope. Thank you.

Philip G. Millam 
Approximate completion time 17 minutes

*The only purpose of this code number is to facilitate possible follow-up action.

This section of the questionnaire is designed to determine some basic background data on each individual tested. In many ways it is similar to an employment application form.

1. What is the title of your present position as show on official job description charts? (optional)

2. G.S. level (please specify):

3. Your present position is best characterized as: Line Staff

4. Sex: Male Female 5. Age (please state):

6. Have you ever attended or are you now attending the BPA Basic Supervisory Development Workshop? Yes No

7. Please state the city and state (or foreign country) where you. attended the greatest portion of high school. City or town: State:

8. Extent of formal schooling: (please check only the highest level attained.)
a. Some high school
b. High school graduate
d. College graduate.
e. Post-graduate study

c. Some college

9. If you answered $c, d$, or $e$ in \#8 above, please fill in the following for any college or post-graduate study. Institution (s) attended

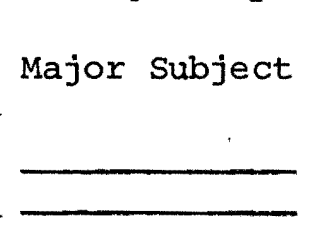

Degree, if

received (BS, MA etc.)
Year degree received or years attended

10. Career pattern:

a. Please list, in chronological order, employers for whom you worked prior to coming to BPA. Please do not include part time or temporary work unless it was significant to your career.

Position

Firm or agency

Length of time

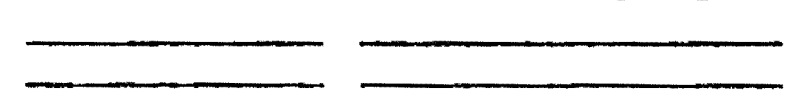

employed 
b. Please list briefly the positions you have held since coming to BPA and the approximate length of time in each position. please list them in chronological order.

Position and G.S. level

Length of time held

11. What year did you begin working for BPA?

12. If you were to leave BPA for any reason, for whom would you consider working? (Please specify the firm or agency.)

a.

b.

c.

13. This section of the questionnaire is designed to determine degree of agreement or disagreement on several statements. Please circle the number following the question that most nearly conforms with your views on the issue. d.

e.

f.
SCAIE

$1=$ Strongly agree

2 = Mildly agree

$3=$ Neutral

$4=$ Mildly dísagree

5 = Strongly disagree

a. "BPA has the responsibility to do what it can to prevent a

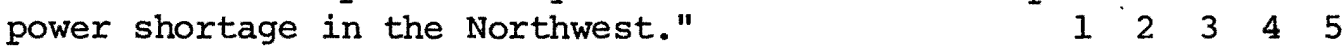

b. "From hindsight, it was a mistake to encourage the aluminum reduction plants to come to the Northwest." $\quad 1 \quad 2 \quad 3-445$

c. "Any BPA employee can air his disagreement on policy matters without fear of formal or informal pressures being brought against him."

d. "The environmentalists generally have become too concerned with their narrow goals and not concerned enough with the

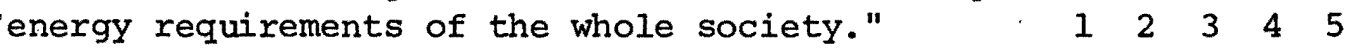

e. "Power contracts with private power utilities should be cancelled if such action is necessary to insure adequate electrical energy for public power groups." $\quad \begin{array}{llllll} & 2 & 3 & 4 & 5\end{array}$

f. "The continued growth of business and industry is necessary if we are to maintain the high standard of living that we enjoy here in the Northwest."

g. "BPA should take a part in reducing the rate of economic expansion in the Northwest with policies that restrict availability of power."

h. "Marketing power and promoting the conservation of power are compatible functions for BPA." 
i. "Generally speaking, the public is very interested in

and aware of the policies and activities of BPA." $1124 \quad 3 \quad 4 \quad 5$

$j$. "In general, BPA is very responsive to the wishes of

the groups that it serves." $\quad 1 \quad 2 \cdot 3 \quad 4 \quad 5$

k. "BPA should become more actively involved in. the promotion of conservation of electric energy."

$\begin{array}{lllll}1 & 2 & 3 & 4 & 5\end{array}$

14. What group or groups benefit most from BPA policies?

(1)

(3)

15. From your perspective, which groups or individuals (both inside and outside of $B P A$ ) have the most influence on BPA policy? Please list them in order of importance.

(1)

(3)

(4)

16. Please respond in as much detail as you wish to the following questions :

a. What steps (technical, political, social, and/or economic) do you personally feel that BPA and the public must take in order to prevent or alleviate the power shortages forecasted for the Northwest in the future? (Please list your "program" with the most important steps first, and so on.)

(Please continue your response on the back of this sheet if you require additional space.)

b. What is the official mission of BPA?

c. If the mission of BPA should be (in your opinion) different from what you have expressed above, please describe what that mission ought to be.

17. To what extent do you feel that your opinions and advice influence

your supervisor(s)? (Please check one.)

No influence

Little influence

Some influence Much influence

Thank you for your time and cooperation. A finished copy of the thesis will be made available to the BPA library. Please mail the completed questionnaire in the attached, stamped envelope to:

BPA Executive Study

Department of Political Science

Portland State University

Portland, Oregon 97207

(please remove and dispose of the top two cover sheets and mail only the questionnaire portion) 